\title{
Bone microstructure and the evolution of growth patterns in Permo-Triassic therocephalians (Amniota, Therapsida) of South Africa
}

Therocephalians were a speciose clade of nonmammalian therapsids whose ecological diversity and survivorship of the end-Permian mass extinction offer the potential to investigate the evolution of growth patterns across the clade and their underlying influences on post-extinction body size reductions, or 'Lilliput effects.' We present a phylogenetic survey of limb bone histology and growth patterns in therocephalians from the Middle Permian through Middle Triassic of the Karoo Basin, South Africa. Histologic sections were prepared from 80 limb bones representing 11 genera of therocephalians. Histologic indicators of skeletal growth, including cortical vascularity (\%CV) and mean primary osteon diameters (POD), were evaluated in a phylogenetic framework and assessed for correlations with other biologically significant variables (e.g., size and robusticity). Changes in \%CV and POD correlated strongly with evolutionary changes in body size (i.e., smaller-bodied descendants tended to have lower \%CV than their larger-bodied ancestors across the tree). Bone wall thickness tended to be high in early therocephalians and lower in the gracile-limbed baurioids, but showed no general correlation with cross-sectional area or degree of vascularity (and, thus, growth). Clade-level patterns, however, deviated from previously studied within-lineage patterns. For example, Moschorhinus, one of few therapsid genera to have survived the extinction boundary, demonstrated higher \%CV in the Triassic than in the Permian despite its smaller size in the extinction aftermath. Results support a synergistic model of size reductions for Triassic therocephalians, influenced both by within-lineage heterochronic shifts in survivor taxa (as reported in Moschorhinus and the dicynodont Lystrosaurus) and phylogenetically inferred survival of small-bodied taxa that had evolved short growth durations (e.g., baurioids). These findings mirror the multi-causal Lilliput patterns described in marine faunas, but contrast with skeletochronologic studies that suggest slow, prolonged shell secretion over several years in marine benthos. Applications of 
phylogenetic comparative methods to new histologic data will continue to improve our understanding of the evolutionary dynamics of growth and body size shifts during mass extinctions and recoveries. 
1 Bone microstructure and the evolution of growth patterns in Permo-Triassic

2 therocephalians (Amniota, Therapsida) of South Africa

5 Adam K. Huttenlocker*

6 Department of Biology and Burke Museum of Natural History and Culture, University of

7 Washington, Seattle, Washington 98195, U.S.A. Email: ahuttenlocker@gmail.com;

9 and

11 Jennifer Botha-Brink

12 Department of Karoo Palaeontology, National Museum and Department of Zoology and

13 Entomology, University of the Free State, Bloemfontein 9300, South Africa; Centre of Excellence

14 in Palaeosciences, University of Witwatersrand, Johannesburg 2050, South Africa. Email:

15 jbotha@nasmus.co.za.

*Corresponding author; Current address: Department of Biology, University of Utah, and Natural

21 History Museum of Utah, Salt Lake City, Utah, USA 84112-0840

2441 pages, 1 appendix, 2 tables, 7 figures, and 1 supporting file w/ 10 supporting figures

Abstract-Therocephalians were a speciose clade of nonmammalian therapsids whose 
ecological diversity and survivorship of the end-Permian mass extinction offer the potential to

27 investigate the evolution of growth patterns across the clade and their underlying influences on

28 post-extinction body size reductions, or 'Lilliput effects.' We present a phylogenetic survey of

29 limb bone histology and growth patterns in therocephalians from the Middle Permian through

30 Middle Triassic of the Karoo Basin, South Africa. Histologic sections were prepared from 80

31 limb bones representing 11 genera of therocephalians. Histologic indicators of skeletal growth,

32 including cortical vascularity $(\% \mathrm{CV})$ and mean primary osteon diameters (POD), were evaluated

33 in a phylogenetic framework and assessed for correlations with other biologically significant

34 variables (e.g., size and robusticity). Changes in \%CV and POD correlated strongly with

35 evolutionary changes in body size (i.e., smaller-bodied descendants tended to have lower \%CV

36 than their larger-bodied ancestors across the tree). Bone wall thickness tended to be high in early

37 therocephalians and lower in the gracile-limbed baurioids, but showed no general correlation with

38 cross-sectional area or degree of vascularity (and, thus, growth). Clade-level patterns, however,

39 deviated from previously studied within-lineage patterns. For example, Moschorhinus, one of few

40 therapsid genera to have survived the extinction boundary, demonstrated higher $\% \mathrm{CV}$ in the

41 Triassic than in the Permian despite its smaller size in the extinction aftermath. Results support a

42 synergistic model of size reductions for Triassic therocephalians, influenced both by within-

43 lineage heterochronic shifts in survivor taxa (as reported in Moschorhinus and the dicynodont

44 Lystrosaurus) and phylogenetically inferred survival of small-bodied taxa that had evolved short

45 growth durations (e.g., baurioids). These findings mirror the multi-causal Lilliput patterns

46 described in marine faunas, but contrast with skeletochronologic studies that suggest slow,

47 prolonged shell secretion over several years in marine benthos. Applications of phylogenetic

48 comparative methods to new histologic data will continue to improve our understanding of the

49 evolutionary dynamics of growth and body size shifts during mass extinctions and recoveries. 


\section{Introduction}

52 Mass extinctions are frequently followed by short-term reductions in body sizes of

53 survivor lineages, a pattern known as the 'Lilliput effect' (Urbanek, 1993; Harries, Kauffman \&

54 Hansen, 1996). However, in the absence of adequate phylogenetic and life history data, the

55 mechanisms of size reductions can be unclear and likely differ across environments, taxonomic

56 groups, and extinction events (Twitchett, 2007; Harries and Knorr, 2009). Lilliput patterns have

57 been documented widely in marine invertebrate groups following the end-Permian extinction

58 (Payne, 2005; Twitchett, 2007; Luo et al., 2008; Mutter and Neuman, 2009; Metcalfe, Twitchett

59 \& Price-Lloyd, 2011; Song, Tong \& Chen, 2011; Rego et al., 2012), and anecdotally in tetrapods

60 of the Triassic Lystrosaurus Assemblage Zone in the Karoo Basin of South Africa (ca. 252.3 Ma),

61 but growth dynamics underlying these patterns are not fully understood. Therocephalians

62 represent an exemplary clade of nonmammalian therapsids that thrived from the Middle Permian

63 to Middle Triassic, and survived the end-Permian extinction as important components of Triassic

64 survivor and recovery faunas in the Karoo Basin (Botha and Smith, 2006). In addition to the

65 dicynodont Lystrosaurus, at least three genera of therocephalians in two major groups have

66 observed stratigraphic occurrences that span the extinction boundary in the Karoo: the baurioid

67 Tetracynodon, and the akidnognathids Promoschorhynchus and Moschorhinus (Smith and Botha,

68 2005; Botha and Smith, 2006; Huttenlocker, Sidor \& Smith, 2011). Other Triassic taxa (e.g.,

69 Olivierosuchus, Regisaurus) have long ghost lineages extending into the Permian, indicating that

70 they too survived the extinction but lack a Permian record within the depositional basin

71 (Huttenlocker, 2009; Huttenlocker, Sidor \& Smith, 2011). Although therocephalians are generally

72 exceeded in abundance by dicynodont therapsids in the Karoo Basin, their diversity, extensive

73 stratigraphic range, and success during the end-Permian extinction make them an ideal group to

74 study evolutionary patterns during the Permian-Triassic transition. 
Previous morphological studies of therocephalians have emphasized their functional

anatomy, including jaw mechanics and locomotory specializations (e.g., Kemp, 1972, 1978,

1986; Fourie and Rubidge, 2007, 2009). Recent collaborative work on therocephalians has

emphasized integration of their fine structure and internal anatomy to resolve paleobiological

questions, including tooth replacement patterns, braincase structure, and growth and

histomorphologic structure (Abdala, Rubidge \& van den Heever, 2008; Sigurdsen et al., 2012;

Huttenlocker and Botha-Brink, 2013). Detailed investigations of histmorphology are particularly useful, permitting assessments of growth patterns and variation within or among closely related therapsid species (e.g., Botha and Angielczyk, 2007; Huttenlocker and Botha-Brink, 2013).

Moreover, as growth patterns are associated with organismal fitness, recent investigations into bone microstructure have inquired into whether certain growth strategies conferred success on some groups during the end-Permian mass extinction (e.g., rapid growth in the dicynodont Lystrosaurus and its relatives; Botha-Brink and Angielczyk, 2010).

\section{Bone Microstructure in Therapsids}

Bone histology has offered insights into the lifestyles and growth patterns of many of the major subclades of nonmammalian therapsids. Recent examples include investigations of feeding and locomotion, habitat use, and especially growth dynamics (e.g., Ray, Chinsamy \& Bandyopadhyay, 2005; Jasinoski, Rayfield \& Chinsamy, 2010; Chinsamy-Turan, 2012). Earlier surveys of bone histology emphasized differences between basal (pelycosaurian-grade) synapsid and therapsid tissue composition, matrix organization, and degree of vasculature of the limb bones (Enlow and Brown, 1957; Enlow, 1969; Ricqlès, 1969, 1974a, 1974b, 1976). Particularly, fibrolamellar tissue complexes (vascularized bone tissues that incorporate primary osteons within a woven-fibered matrix) were found to be near ubiquitous among limb elements of sampled therapsids, suggesting that this tissue complex appeared early during therapsid evolution prior to the origination of mammals bearing this tissue-type (Ricqlès, 1969, 1974a, b; Ray, Botha \& 
100 Chinsamy, 2004; Chinsamy and Hurum, 2006; Ray, Bandyopadhyay \& Bhawal, 2009). Indeed,

101 fibrolamellar bone has been reported in basal therapsids (e.g., Biarmosuchus: Ricqlès, 1974b), as

102 well as in some immature pelycosaurian-grade synapsids (e.g., Sphenacodon and Dimetrodon

103 juveniles) and in fast-growing portions of the skeleton (e.g., the elongated neural spines of

104 Dimetrodon and crossbars on the neural spines of Edaphosaurus) (Huttenlocker, Rega \& Sumida,

105 2010; Huttenlocker, Mazierski \& Reisz, 2011; Huttenlocker and Rega, 2012; Shelton et al.,

106 2013). However, there is great histovariability in the organization of fibrolamellar bone even

107 within major subclades of therapsids. Fibrolamellar bone may be formed by varying degrees of

108 woven- and parallel-fibered interstitial matrix and incorporates a variety of vascular motifs, and

109 may be zonal (punctuated by cyclic growth marks) or azonal. Ray, Botha \& Chinsamy (2004)

110 reported the presence of zonal fibrolamellar bone in many Permian and Middle Triassic taxa, but

111 suggested that sustained (non-cyclic) growth patterns might have arisen occasionally in a number

112 of phylogenetically disparate taxa that do not encompass the immediate ancestors of mammals

113 (gorgonopsian Aelurognathus; eucynodont Cynognathus; and some bidentalian dicynodonts). The

114 abundance of dicynodont fossils in Permian and Triassic rocks and recent advances in their

115 systematic relationships have permitted more detailed comparisons of growth patterns in this

116 diverse subclade (Chinsamy and Rubidge, 1993; Botha, 2003; Ray and Chinsamy, 2004; Ray,

117 Chinsamy \& Bandyopadhyay, 2005; Botha and Angielczyk, 2007; Ray, Bandyopadhyay \&

118 Bhawal, 2009; Botha-Brink and Angielczyk, 2010; Green, Schweitzer \& Lamm, 2010;

119 Nasterlack, Canoville \& Chinsamy-Turan, 2012; Ray, Botha-Brink \& Chinsamy-Turan, 2012).

120 Phylogenetic comparative surveys have revealed patterns of increasing tissue vascularity during

121 the evolutionary history of bidentalian dicynodonts (especially in Triassic forms like

122 Lystrosaurus), and determinate growth patterns with peripheral rest lines and systematic cortical

123 remodeling in large kannemeyeriiforms (Botha-Brink and Angielczyk, 2010; Green, Schweitzer

124 \& Lamm, 2010; Ray, Botha-Brink \& Chinsamy-Turan, 2012). 
126 phylogenetic and temporal distributions, is incompletely known. A body of literature on

127 nonmammalian cynodont histology has accrued in recent years (e.g., Ricqlès, 1969; Botha and

128 Chinsamy, 2000, 2004, 2005; Ray, Botha \& Chinsamy, 2004; Chinsamy and Abdala, 2008;

129 Botha-Brink, Abdala \& Chinsamy-Turan, 2012), but sampling has been more limited in other

130 theriodonts, such as the gorgonopsians and therocephalians (Ray, Botha \& Chinsamy, 2004;

131 Chinsamy-Turan and Ray, 2012; Huttenlocker and Botha-Brink, 2013). Ricqlès (1969) suggested

132 differential rates of growth between a basal therocephalian from the Middle Permian of South

133 Africa and the Late Permian whaitsiid 'Notosollasia' (=Theriognathus). Given the comparatively

134 more vascularized cortical bone in the radius of the whaitsiid (1969: plate IV), Ricqlès suggested

135 that therocephalians might have exhibited accelerated growth rates later in their evolutionary

136 history, paralleling the aforementioned temporal pattern of increasing growth rates in some

137 dicynodonts. More recently, Ray, Botha \& Chinsamy (2004) and Chinsamy-Turan and Ray

138 (2012) analyzed additional material from an indeterminate scylacosaurid (erroneously identified

139 as 'Pristerognathus'), in addition to other therapsid material, and argued for similar 'flexible'

140 growth patterns in gorgonopsians, basal therocephalians, and most early cynodonts. The authors

141 suggested that more rigorous taxonomic sampling would better substantiate parallel trends toward

142 a loss in developmental plasticity and acceleration of growth rates as in dicynodonts. Inadequate

143 sampling of eutherocephalians before and after the end-Permian mass extinction limits our

144 understanding of evolutionary patterns in therapsid histomorphology and skeletal growth during

145 this important geologic transition.

\section{Present Study}

147 Although eutherocephalians have not been sampled histologically for such comparisons,

148 recent revisions to Permo-Triassic boundary-crossing taxa have necessitated cursory descriptions

149 of eutherocephalian histology for its ontogenetic and paleobiological implications (e.g., 
150 Tetracynodon: Sigurdsen et al., 2012; Moschorhinus: Huttenlocker and Botha-Brink, 2013).

151 During the course of this work, we developed a database of histological data and images with the

152 goal of addressing features of life history evolution in Permian and Triassic eutheriodonts

153 (therocephalians and cynodonts), particularly in the context of the end-Permian extinction. Here,

154 we present a reappraisal of limb bone microstructure in Permian and Triassic therocephalians

155 based on new histologic sampling, and offer a hypothesis of the evolution of their growth

156 patterns. We suggest that therocephalians provide a robust study system for investigating the

157 evolution of growth strategies during the Permian-Triassic transition, and a useful point of

158 comparison and contrast to other groups that lived during this time (e.g., dicynodonts,

159 cynodonts).

160

161 Materials and Methods

\section{Specimen Selection and Histological Processing}

163 Specimens were selected based on completeness and availability for histological

164 processing, but a broad sample of the major representatives of South African therocephalians was

165 desired in order to recognize long-term patterns (if present) or clade specific histomorphology.

166 Specimens that were semi-articulated and included diagnostic cranial material were preferred for

167 accuracy of taxonomic identifications. Some specimens were not diagnosable to genus, but were

168 resolved to their respective higher taxon as in the case of five indeterminate scylacosaurids

169 described here. Scylacosaurids are generally difficult to identify unless a complete and accurate

170 antecanine tooth count can be made, and some authors have suggested that the diversity of

171 scylacosaurids is over-split because variations in tooth count may be ontogenetically variable

172 (e.g., Abdala, Rubidge \& van den Heever, 2008). The sample therefore included 80 limb elements

173 from 33 individuals in 11 genera: Lycosuchus, Glanosuchus, Moschorhinus, Olivierosuchus, 
174 Hofmeyria, Mirotenthes, Theriognathus, Ictidosuchoides, Tetracynodon, Scaloposaurus, and

175 Microgomphodon (Fig. 1), plus additional scylacosaurid material not diagnosed to genus. Thin-

176 sections were prepared using standard histological techniques modified from Chinsamy and

177 Raath (1992) and Wilson (1994). Limb bone midshafts were sampled cross-sectionally and

178 imaged using Nikon Eclipse 50i and LV100 POL petrographic microscopes with a digital image

179 capture system. Histomorphometric variables (discussed below) were measured using NIS-

180 Elements and NIH ImageJ v. 1.42q software (Rasband, 1997-2012). Moschorhinus

181 histomorphology was excluded from present description as it has been discussed elsewhere

182 (Huttenlocker and Botha-Brink, 2013), but data from Moschorhinus were included in the

183 quantitative analyses (Table 1).

\section{Bone Tissue Typology: Definitions and Selection of Growth Proxies}

185 Bone tissue texture exhibits marked variation in therocephalians and other therapsids,

186 varying from highly organized and lamellar to disorganized and woven. Only a few recent studies

187 have integrated qualitative and quantitative assessments of tissue texture and vascular proxies of

188 growth in Permo-Triassic therapsids (Botha and Chinsamy 2000, 2004, 2005; Ray and Chinsamy

189 2004; Ray et al., 2004, 2005, 2010; Botha-Brink and Angielczyk 2010; Huttenlocker and Botha-

190 Brink, 2013). Generally, cellular bone forms as osteoblasts become incorporated into the

191 extracelluar (or interstitial) matrix (ECM) forming quiescent osteocytes. The overall bone

192 apposition rate affects the texture of the mineralized ECM, with collagen fibers and crystallites

193 bearing a more lamellar organization under slower growth and a nonlamellar (woven-fibered)

194 texture under faster growth. Parallel-fibered bone, an intermediate tissue-type, can be identified

195 by its 'streaky' appearance under polarized light, with the predominant fiber orientation being

196 parallel to the surface of the bone and forming a woven-basket texture in most cases. In cases in

197 which birefringent properties have been disrupted by diagenetic processes, it is possible to

198 approximate the relative organization of mineralized fibers with reference to the organization of 
199 the lacunocanalicular network within the ECM (Stein and Prondvai, 2013). In contrast to parallel-

200 fibered bone, woven-fibered bone includes large, globular osteocyte lacunae that are usually

201 densely packed within the mineralized ECM. Nonlamellar tissues (parallel- and woven-fibered)

202 may also frequently incorporate large vascular canals that later become infilled with one or two

203 concentric lamellae forming primary osteons (diagnosed by their 'Maltese cross' pattern of

204 birefringence under polarized light). These osteons house passageways for blood vessels and

205 nerves while also contributing to the structural integrity of the bone by providing added bone

206 mass and helping to blunt microcracks (Currey, 2002). The result is a fibrolamellar bone complex

207 (herein 'FLB'), in which a disorganized, fibrous or nonlamellar interstitial matrix incorporates an

208 anastomosing network of centripetally lamellated primary osteons. Currey $(1987,2002)$ defined

209 FLB broadly as a tissue complex formed by parallel- (or woven-) fibered bone with primary

210 osteons (2002: p.18). By contrast, Ricqlès (1974a) originally restricted the term 'fibrolamellar' to

211 tissues formed largely by woven-fibered bone with primary osteons, excluding parallel-fibered

212 bone from this category. Herein, we follow the traditional usage of Ricqlès, but temper this strict

213 definition by noting that parallel- and woven-fibered bone form a continuum that is often ill-

214 defined (and may be present simultaneously in many therapsid bony tissues, even within the same

215 section). Bone cortices formed primarily by lamellar tissue, which forms at relatively slower

216 apposition rates $(\sim 1 \mu \mathrm{m} /$ day or less) (Margerie et al., 2002; Lee et al., 2013), do not typically

217 incorporate primary osteons, instead bearing simple vascular canals or being avascular. In

218 lamellar bone, the lacunocanalicular network is ordered, the osteocyte lacunae being small and

219 more lenticular in appearance with the long axis oriented parallel to the surface of the bone. Both

220 tissue complexes can be zonal (periodically interrupted by growth marks) or azonal. Growth

221 marks in zonal bone may be present in the form of lines of arrested growth or 'LAGs' (denoted

222 by an opaque cement line, traceable around the entire cortex, and indicative of a temporary

223 cessation of growth) or annuli (thin bands of dense, annular tissue, usually parallel-fibered or 
224 lamellar, deposited during periods of slowed growth).

225 For quantitative histomorphometric analysis, two vascular proxies of skeletal growth were

226 selected: cortical vascularity and mean primary osteon diameter. These proxies were selected in

227 order to evaluate the extent to which histological correlatives of growth varied across phylogeny,

228 and whether their evolution was tied to body size or other biological factors. Vascular proxies

229 have offered useful indicators of skeletal growth in extant and extinct tetrapods (Castanet et al.,

230 2000; Margerie et al., 2002, 2004; Buffrénil, Houssaye \& Böhme, 2007; Cubo et al., 2012), and

231 their utility here allows comparisons with other histological studies of therapsids in which similar

232 measures were used (e.g., Botha-Brink and Angielczyk 2010; Huttenlocker and Botha-Brink,

233 2013). Notably, ontogenetic variation in growth may introduce a lesser degree of cortical

234 vascularity in adult bones that exhibited decreasing apposition rates prior to death and burial, and

235 may therefore introduce variation in a single cross-section where this transition is recorded.

236 Nonmammalian therapsids, however, are well suited to relative growth rate estimation based on

237 tissue texture and vascularity, due to their generally thick bone walls (preserving the early record

238 of primary growth) and limited secondary remodeling (Botha-Brink and Angielczyk, 2010).

239 Measurement of cortical vascularity $(\% \mathrm{CV}$, the relative area of the cortex that is occupied by

240 porous, vascular spaces) follows Lee et al. (2013). Measurements were restricted to the inner

241 two-thirds to three-quarters of the cortex where the bone formed at high, sustained growth rates

242 (Cubo et al., 2012), and were averaged from ten quadrants sampled circularly around each

243 midshaft cross-section. The subsampled quadrants excluded areas of secondary reconstruction

244 and outer regions of simple canals. We also estimated mean primary osteon diameter $(P O D)$ by

245 measuring in microns the transverse (or minimum) widths of 15 primary osteons visible in the

246 subsampled regions and averaging them across all regions within a given midshaft cross-section.

247 To examine potential effects of size and robusticity on measured histomorphometric

248 variables, we also estimated two proxies of overall bone robusticity: (1) $K$ (the proportional 
249 diameter of the medullary region relative to the total diameter of the cross-section; Currey and

250 Alexander, 1985) and (2) relative bone wall thickness or ' $R B T$ ' (the percentage of the average

251 cross-sectional thickness of the bone wall relative to the total diameter of the cross-section;

252 Chinsamy, 1993). These variables play a frequent role in histological studies of fossil tetrapod

253 bone, as bone robusticity may correspond to habitat preferences or mechanical loading (Wall,

254 1983; Currey and Alexander, 1985; Currey, 2002; Laurin, Girondot \& Loth, 2004; Germain and

255 Laurin, 2005; Kriloff et al., 2008). However, their relationships to size, growth, and vascularity

256 have been underexplored in a comparative framework. These measurements, as well as cross-

257 sectional area at midshaft, were attained using NIH ImageJ, and were tested for correlations with

258 vascular growth proxies using Pearson's product-moment correlation tests. Histomorphometric

259 data are recorded in Table 1.

260 Correlation Tests

261 Pearson's product-moment correlation tests-We performed a series of correlation

262 tests in order to evaluate the extent to which variations in vascular growth proxies were

263 dependent upon size and robusticity, which bear a strong influence on many aspects of

264 organismal biology (Peters, 1983; Calder, 1984; Stearns, 1992). For instance, small-bodied

265 therocephalians might have achieved their increasingly diminutive sizes by having a slower

266 growing, less vascularized skeleton compared to their larger-bodied predecessors. In this

267 scenario, one would expect a correlation between smaller size and slower growth, and between

268 larger size and faster growth across subclades. A similar correlation in which small-bodied

269 species generally exhibit slower growth rates than larger-bodied groups has been identified in

270 extant vertebrates (Case, 1978), and suggested by histologic data in fossil non-avian dinosaurs

271 (Erickson et al., 2004; Lee, 2007). On the other hand, smaller sizes may have been achieved by

272 shortening the duration of the growth period, in which case no generalized correlations between

273 size and vascular proxies of skeletal growth are necessary. To address these hypotheses, 
274 histomorphometric data $(\% C V, P O D, R B T)$ and midshaft cross-sectional area were recorded for

275 each sectioned limb bone. The data were organized into propodial, epipodial, and pooled subsets

276 to control for the effects of increased variance from pooling limb bones of different types

277 (although the effects appeared to be minimal as all tests ultimately yielded similar results). For

278 each data partition, Pearson's product-moment correlation tests were performed between

279 histomorphometric variables $(\% C V, P O D, R B T)$ and the natural log of midshaft cross-sectional

280 area. Vascular growth proxies were also tested for correlations with bone robusticity independent

281 of size, and with each other to assess whether $\% C V$ and $P O D$ provided comparable estimates of

282 vascularization.

283 Phylogeny-independent contrasts - Independent contrast methods were carried out to

284 control for the effects of phylogenetic non-independence of putative correlations (Felsenstein,

285 1985; Garland, Bennett \& Rezende, 2005). For example, one might find low tissue vascularity in

286 Triassic baurioids due to their generally small sizes, or due to their close relatedness (and, by

287 extension, their inherited phenotypic similarities). We carried out additional correlation tests on

288 an augmented data set using the PDAP:PDTREE module (Midford et al., 2011) in Mesquite

289 version 2.0 (Maddison and Maddison, 2007). This required a tree and branch lengths (adapted

290 from Huttenlocker, 2013, 2014) pruned to the 11 histologically sampled taxa. First, tip data for

291 each of the 11 taxa were recorded in a NEXUS file, including average $\% C V, P O D, R B T$ and the

292 natural $\log$ of midshaft area of the propodials and epipodials separately (limb bones were not

293 pooled for independent contrasts). Second, ancestral character states (estimated using squared-

294 change parsimony) were checked for the assumption of Brownian motion evolution that governs

295 independent contrasts (Felsenstein, 1985; Díaz-Uriarte and Garland, 1996). This was performed

296 by running assumption-testing operations in PDAP that evaluate the relationship between the

297 absolute values of independent contrasts and their corresponding standard deviations. Non-

298 significant relationships were determined for each of the data partitions, indicating that a 
Brownian motion model adequately fit the tip data. Finally, the same sets of regressions were

300 performed on independent contrasts as in the untransformed data (size, robusticity, and vascular

301 growth proxies).

302

303 Results

304 Results1: Qualitative Histomorphology

305 Due to space limitations, the present description is accompanied by a more detailed

306 account in the Supporting Data file. In general, limb bone cortices in studied therocephalians

307 were thick and formed primarily by FLB with varying degrees of vascularization, depending on

308 size and phylogenetic position. For example, large basal therocephalians from the Middle

309 Permian exhibited subplexiform FLB in the propodial elements with a comparatively high degree

310 of vascularization ( $\% C V \sim 13-16 \% ; P O D \sim 75-168 \mu \mathrm{m})$. By contrast, some smaller-bodied taxa

311 in both the Permian and Triassic tended to incorporate more parallel-fibered bone or showed

312 evidence of increased parallel-fibered and lamellar bone deposition with less vasculature toward

313 the outer cortex, indicative of growth attenuation and attainment of somatic maturity (Margerie,

314 Cubo \& Castanet, 2002). This pattern is marked in Mirotenthes, which preserves an external

315 fundamental system ('EFS') in some elements (an outer collar of avascular, generally acellular,

316 lamellar bone indicative of virtual cessation of circumferential growth in adult individuals;

317 Cormack, 1987; Huttenlocker, Woodward \& Hall, 2013). Systematic cortical remodeling by

318 Haversian bone formation was rare and only a few sparse secondary osteons were identified in

319 some Permian scylacosaurian taxa [e.g., an indeterminate scylacosaurid and Moschorhinus,

320 contrary to reports of extensive skeletal remodeling by Chinsamy-Turan and Ray (2012: p. 203)].

321 As in dicynodonts and other therapsids in which histology is well known, most basal

322 therocephalians and eutherocephalians exhibited remarkably thick bone walls ( $\sim 20-35 \% R B T$ in 
323 forelimb elements of lycosuchids, scylacosaurids, and akidnognathids; $\sim 40 \%$ in forelimbs of

324 hofmeyriids). This condition, however, was lost in baurioids, which were instead characterized by

325 a much thinner cortical bone wall $(<25 \%$ in the forelimb and propodials $)$ and more slender limb

326 bones.

327 Permian basal therocephalians and eutherocephalians (Fig. 2A-C, F, G; Fig. 3A, B)

328 generally showed multiple growth zones as well, demarcated by cyclic growth marks indicative

329 of periodic pauses in growth as in other Permian therapsids (Ray et al., 2004, 2012; Botha-Brink

330 and Angielczyk, 2010; Botha-Brink et al., 2012). Although Triassic therocephalians (Fig. 2D, E;

331 Fig. 3C-F) showed a variety of vascular motifs and tissue-types (e.g., richly vascularized and

332 disorganized bone tissues in akidnognathids; less vascularized parallel-fibered bone tissue in

333 baurioids), fewer growth marks were recorded in all Triassic species. Small Triassic baurioids in

334 particular showed thinner bone walls with few growth marks, less vascularized limb bone

335 cortices, and smaller, more sparsely distributed primary osteons on average.

337 Results 2: Quantitative Histometrics

338 Pearson's correlation and phylogeny-independent contrasts-Results of raw and

339 phylogeny-corrected correlation tests are presented in Table 2. Correlation tests on raw data

340 found that vascular growth proxies were strongly positively correlated with size [i.e., the natural

$341 \log$ of midshaft cross-sectional area, underscoring greater overall tissue vascularity in large bones

342 from larger taxa (e.g., Lycosuchus, scylacosaurids, Moschorhinus)] (Fig. 4; Table 2). Both \%CV

343 and $P O D$ also exhibited a strong positive correlation with each other, indicating that $\% C V$ and

$344 P O D$ represent equivalent proxies for understanding relationships between bone tissue

345 vascularization and growth across the therocephalian clade. Whereas the selected vascular growth

346 proxies shared a consistent positive relationship with size for all data partitions, putative

347 associations between robusticity and size were less clear. Correlation tests on raw size data and 
$348 R B T$ were non-significant. Likewise, correlation tests on raw vascular growth proxies and $R B T$

349 either yielded non-significant $p$-values or, in the case of the propodial-only data partition, had low

350 correlation coefficients with only a weakly positive association. This result is likely due to the

351 fact that even some small-bodied taxa exhibited unexpectedly thick bone walls, as in the case of

352 the hofmeyriids Hofmeyria and Mirotenthes. Bone wall thickness correlates poorly with size and

353 growth proxies, suggesting that bone robusticity is not necessarily tied directly to growth

354 (perhaps being constrained by ecology, habitat, or mechanical regimen in different groups of

355 therocephalians).

356 Results of phylogeny-corrected correlations further indicated a strong relationship

357 between size and some histometrics (but not with limb bone robusticity) (Table 2). Evolutionary

358 decreases in cross-sectional area of limb bones were generally associated with decreases in

359 average \%CV and $P O D$. Eutherocephalians and particularly baurioids demonstrated a noteworthy

360 pattern in which reconstructed ancestor-descendant size reductions of Late Permian and Triassic

361 lineages were associated with decreases in the average level of tissue vascularization. Patterns in

362 limb bone robusticity were less clear. As in the analyses of the raw data, phylogeny-corrected

363 correlations between $R B T$ and size or growth proxies were non-significant.

\section{Discussion}

\section{General Histological Patterns}

367 Size, robusticity, and vascular growth proxies-Biologically meaningful associations

368 are detectable in therocephalian histology, as in some other therapsid groups. For example,

369 vascular growth proxies were strongly positively correlated with size as larger-bodied species

370 typically exhibited greater overall tissue vascularity (e.g., Lycosuchus, scylacosaurids,

371 Moschorhinus). Previous tests incorporating a large histologic sample of dicynodonts and other 
372 therapsids found similar correlations between raw vascular growth proxies and size (estimated

373 from skull lengths), although tests on a subset of dicynodonts were only marginally significant

374 and non-significant when independent contrasts were evaluated (Botha-Brink and Angielczyk,

375 2010). The new data agree with these earlier results by large measure. However, the present

376 analysis found a strongly positive correlation between size and both vascular growth proxies

377 (\%CV and $P O D)$ even when corrected for phylogeny. Prior analyses implementing phylogeny-

378 independent contrasts on dicynodonts were unable to identify similar patterns, despite a

379 significant correlation between the raw data (Botha-Brink and Angielczyk, 2010). Improved

380 statistical results in this study are a likely consequence of sampling bones of particular types

381 separately (rather than averaging vascularity across all bones) and using cross-sectional

382 measurements from sampled bones as a size proxy (rather than representative skull lengths from

383 specimens that were not sampled histologically). Tests on raw cortical thickness (RBT) in

384 dicynodonts also showed no clear association with size or degree of vascularization as in the

385 present study, even though a positive association with size was discovered when corrected for

386 phylogeny. No correlation was observed between bone robusticity $(R B T)$ and size or degree of

387 vascularization in therocephalians (raw or phylogeny-corrected), suggesting that size and rate of

388 growth may have had limited influence over bone robusticity as compared to other aspects of

389 organismal biology such as mechanical regime (e.g., locomotor behavior, stance or gait; Currey

390 \& Alexander, 1985) and ecology or habitat preference (e.g., burrowing, semi-aquatic/aquatic;

391 Wall, 1983; Laurin, Girondot \& Loth, 2004; Germain and Laurin, 2005). Similarly, data on the

392 genus Moschorhinus indicated that overall bone compactness was related to the thickness of the

393 bone wall, but was largely independent of growth and degree of vascularity (Huttenlocker and

394 Botha-Brink, 2013).

395 Phylogenetic Patterns

396 Previous interpretations of growth patterns in early therocephalians were based on limited 
397 information from incomplete specimens (Ricqlès, 1969; Ray, Botha \& Chinsamy, 2004;

398 Chinsamy-Turan and Ray, 2012). Additional specimens described here suggest that at least some

399 large-bodied predators from the Middle Permian, including Lycosuchus and some scylacosaurids,

400 exhibited subplexiform FLB in propodial elements. Some of the larger-bodied predators in the

401 sample also showed the highest degree of cortical vascularization. This is remarkable, as

402 subplexiform FLB is one of the most rapidly deposited tissue-types in archosaurian and

403 mammalian limb bones, and similarly vascularized bone in birds and mammals forms periosteally

404 at a rate generally greater than $15 \mu \mathrm{m} /$ day (Castanet et al., 2000; Margerie, Cubo \& Castanet,

405 2002; Cubo et al., 2012). It is noteworthy that the subplexiform tissue complex, present in

406 Lycosuchus and scylacosaurids, represents the prototype upon which earlier workers first

407 described FLB [see Stein and Prondvai (2013) for a review]. This subplexiform condition is

408 conspicuously lacking in the whaitsiid Theriognathus (Fig. 5) and some later eutherocephalians.

409 Consequently, the evolutionary scenario suggested by Ricqlès (1969) and critically re-examined

410 by Chinsamy-Turan and Ray (2012) should be revised: basal therocephalians exhibited highly

411 vascularized FLB and grew relatively rapidly over many growing seasons but with frequent

412 interuptions, in contrast to some later eutherocephalians (with the exception of the akidnognathid

413 Moschorhinus, which maintained relatively fast growth).

414 Moreover, elevated vascularity and rapid growth may be a characteristic of larger bodied

415 taxa, an interpretation that is supported by observations in other large predatory theriodonts such

416 as the cynodont Cynognathus and some large gorgonopsians (Botha-Brink, Abdala \& Chinsamy-

417 Turan, 2012; Chinsamy-Turan and Ray, 2012). Importantly, evolutionary decreases in body size

418 during the Permian (Huttenlocker, 2013, 2014) were associated with decreases in overall degree

419 of skeletal vascularization. Both hofmeyriids and Theriognathus (in spite of the latter's

420 substantial size) showed modest cortical vascularity and smaller mean primary osteon diameters

421 than in basal lycosuchids, scylacosaurids or akidnognathids, but the baurioids (which are deeply 
422 nested in the tree and generally smaller-bodied) had the least vascularized bone tissues (Fig. 6).

423 These clade-level patterns suggest that reductions in body size of some Late Permian

424 eutherocephalians were coupled with decreased rates of skeletal apposition leading up to the end-

425 Permian extinction, particularly in the baurioid lineage.

\section{Growth and the End-Permian Extinction}

The end-Permian extinction was associated with evidence of temporary body size

428 reductions, restricted primarily to faunas of the earliest Triassic (Induan) (although size

429 reductions in some therapsids may reflect larger-scale patterns of body size evolution tracing

430 back to the Permian; Huttenlocker, 2013, 2014). Such size shifts have been documented

431 previously based on invertebrate burrows, foraminifera, brachiopods, gastropods, bivalves,

432 conodonts, and fish (Twitchett and Barras, 2004; Payne, 2005; Twitchett, 2007; Luo et al., 2008;

433 Mutter and Neuman, 2009; Metcalfe, Twitchett \& Price-Lloyd, 2011; Song, Tong \& Chen, 2011;

434 Rego et al., 2012). Nevertheless, questions remain regarding the evolution of growth patterns and

435 their underlying influence on size shifts (Twitchett, 2007; Harries and Knorr, 2009). For example,

436 organisms may have experienced slower overall growth rates in response to more limited

437 resources or environmental degradation during the Permian-Triassic transition. Growth mark

438 analyses on marine brachiopod shells (i.e., 'Lingula') have indicated slow growth rates with

439 frequent interruptions to growth in earliest Triassic shells (Metcalfe, Twitchett \& Price-Lloyd,

440 2011). The authors attributed their results to suboptimal environmental conditions, including

441 episodes of benthic hypoxia, hypercapnia, ocean acidification, and/or disruptions to primary

442 productivity. Such environmental factors would place strong physiological limits on shell

443 formation. However, identifications of lingulid specimens were tenuous given conservatism in

444 external morphology of the group, and growth marks were only studied in shells from Triassic

445 survival and recovery faunas without being compared to Permian specimens. Alternatively,

446 surviving lineages could have exhibited heterochronic shifts shortening time to maturity (e.g., 
447 progenesis) and thus rapid, sustained growth over a brief growth period. Progenesis is a classic

448 example of an $r$-selection strategy in perturbed or unstable environments (Gould, 1977) and has

449 been identified as a potential mechanism of some Lilliput patterns (Harries, Kauffman \& Hansen,

450 1996). Finally, if shifts in body size distributions were influenced primarily by differential

451 extinction of large- versus small-bodied forms, then there may have been no resulting changes in

452 growth patterns at all (that is to say, changes in growth dynamics are not necessary to explain

453 post-extinction body size distributions).

454 Growth patterns in Permo-Triassic therapsids compared-New data on growth

455 patterns in nonmammalian therapsids, as well as other Permo-Triassic tetrapods, offer the

456 potential to further evaluate patterns of selectivity during mass extinctions (Botha-Brink and

457 Angielczyk, 2010; Botha-Brink and Smith, 2012). Bone histology has been studied in numerous

458 genera of Permian and Triassic dicynodont therapsids (Chinsamy and Rubidge, 1993; Ray, Botha

459 \& Chinsamy, 2004; Ray, Bandyopadhyay \& Bhawal, 2009; Ray, Botha-Brink \& Chinsamy-

460 Turan, 2012) and recent progress in dicynodont paleobiology has permitted evolutionary

461 investigations of their growth patterns (Botha-Brink and Angielczyk, 2010). Increased rates of

462 skeletal growth originated relatively early, either within or prior to the divergence of bidentalian

463 dicynodonts (e.g., Dicynodon, Lystrosaurus) by the early-Late Permian. Medium-to-large Late

464 Permian dicynodonts continued to show patterns of increased cortical vascularity, especially

465 within the Permo-Triassic boundary-crossing genus Lystrosaurus, which demonstrated some of

466 the highest levels of tissue vascularity ( 20\%). Triassic specimens of Lystrosaurus showed

467 relatively higher vascularity and fewer growth marks. In the therocephalian Moschorhinus, the

468 only large therapsid predator to cross the Permian-Triassic boundary, within-lineage size

469 reduction was associated with the maintenance of rapid but attenuating growth over a short

470 period (Huttenlocker and Botha-Brink, 2013). This pattern suggests that Moschorhinus may have

471 been under selection for reaching its adult size relatively more quickly than in other Permian 
472 therocephalians. Notably, Moschorhinus exhibited comparably high levels of tissue vascularity as

473 Lystrosaurus during the Triassic $(\sim 20-25 \%)$.

474 Whereas anecdotal evidence in Lystrosaurus and Moschorhinus is suggestive of within-

475 lineage heterochronic shifts, clade-level patterns introduce a more complex explanation for

476 observed body size reductions in therocephalians. In particular, body size reductions occurred

477 early during the evolution of eutherocephalians and were associated with a lesser degree of

478 cortical vascularity in medium-to-small-bodied Permian and Triassic forms (e.g., hofmeyriids and

479 especially baurioids). The two major subclades of therocephalians that persisted into the earliest

480 Triassic, Akidnognathidae and Baurioidea, revealed distinctly different growth patterns from each

481 other as interpreted through their tissue texture and degree of vascularity. Their histology

482 suggests a bimodality of life history strategies in earliest Triassic therocephalians: small-to-

483 medium akidnognathids with well-vascularized (fast-growing) bone and smaller-bodied baurioids

484 with less vascularized (slower-growing) bone. However, both groups shared a reduced number of

485 growth marks compared to their Permian relatives in addition to their generally smaller sizes.

486 This nuance is not evident from the quantitative analysis based on vascular proxies of growth rate

487 alone, but is evident from growth mark counts in surveyed specimens. Permian theriodonts that

488 have been sampled histologically, including some gorgonopsians, the cynodont Procynosuchus,

489 basal therocephalians, Permian (but not Triassic) specimens of Moschorhinus, hofmeyriids, and

490 Theriognathus, typically showed evidence of prolonged, multi-year growth often to larger body

491 sizes, a pattern that is not represented in earliest Triassic therapsids sampled to date (Botha-Brink

492 and Angielczyk, 2010; Botha-Brink, Abdala \& Chinsamy, 2012).

493 The present discussion of associations between micro- and macrostructure provides a

494 more functional and wholistic context for the evolution of histological features in Permian and

495 Triassic therocephalians. However, it is important to note that the patterns discussed here have

496 not been evaluated quantitatively and therefore merit future investigation. Recent large-scale 
phylogenetic studies in other therapsids have addressed how life history and functional

498 morphology might have contributed to the success of some groups during the Late Permian and

499 Triassic (e.g., bidentalian dicynodonts). For example, the degree of development of the secondary

500 palate has been linked anecdotally to new environmental conditions with the onset of the Early

501 Triassic, particularly a dramatic decline in atmospheric $\mathrm{pO}_{2}$ from the Late Permian and

502 continuing through the Middle and Late Triassic (Retallack, 2003). However, a rigorous

503 collections-based study found no difference between secondary palate length in Permian and

504 Triassic dicynodonts when corrected for size and phylogeny (Angielczyk and Walsh, 2008).

505 Similarly, a bony secondary palate can be found in a number of therocephalian subgroups, both in

506 the Permian and Triassic, and Triassic therocephalian faunas consisted of species both with (e.g.,

507 baurioids) and without (e.g., akidnognathids) a secondary palate (Fig. 7). No clear association

508 with global hypoxia and respiratory efficiency can be made based on this character, and, as a

509 result, other factors may have been more important in maintaining and shaping the evolution of

510 the secondary palate (e.g., feeding mechanics; Thomason and Russell, 1986).

511 Similar studies addressing the possible effects of hypoxia on cortical tissue vascularity

512 have found few differences between Permian and Triassic therapsids, instead demonstrating that

513 highly vascularized tissues with enlarged canals evolved early in bidentalian dicynodonts (Botha-

514 Brink and Angielczyk, 2010). In therocephalians, variation in the degree of vascularization of

515 limb cortices is best explained by size variation observed across clades (Fig. 7). Most smaller-

516 bodied groups exhibited less vascularized limb bone cortices, a character that evolved relatively

517 early in the evolutionary history of eutherocephalians and held over in some small Triassic taxa.

518 The smallest Triassic forms, derived bauroids, typically had lighter, more gracile skeletons with

519 an open medullary cavity, thinner bone walls, and few to no growth marks. In addition to longer,

520 more slender limb bones, they also had an elongate hind foot with a calcaneal tuber on the heel,

521 maxillary bridge forming a bony secondary palate (discussed above), increasingly specialized 
522 multi-cusped teeth, and often lacked a parietal foramen (or reduced the pineal body altogether as

523 in Tetracynodon; Sigurdsen et al., 2012). The selective value of maintaining a parietal eye for

524 temperature regulation and modulating melatonin production may have been diminished in some

525 small, nocturnal or crepuscular baurioid therocephalians, or in short-lived animals less dependent

526 on seasonal cues in photoperiodicity (Roth, Roth \& Hotton, 1986). The latter scenario is

527 consistent with the lack of cyclic bone deposition and paucity of growth marks in small Triassic

528 baurioids (although one genus, Scaloposaurus, is distinguished from other small Triassic

529 baurioids in its retention of the parietal foramen and pineal body).

531 Conclusion

532

A survey of histological patterns in therocephalians found that limb bone cortices

533 composed of thick deposits of FLB with cyclic growth marks were widespread in early

534 therocephalians, but evolutionary decreases in adult body sizes of some clades were associated

535 with reductions in cortical vascularity and skeletal growth leading up to the end-Permian mass

536 extinction. In Permo-Triassic therocephalians, a pattern of multi-year growth to large body size

537 that was common in the Permian was selected against in the earliest Triassic. This conclusion is

538 supported by (1) ecological removal of large-bodied taxa having prolonged, multi-year growth

539 patterns; (2) cladistically inferred survival of small-bodied taxa with modest skeletal apposition

540 rates, but truncated growth durations (i.e., baurioids); and (3) within-lineage shifts in growth

541 patterns observed in boundary-crossing genera in the Karoo (i.e., Lystrosaurus and

542 Moschorhinus). A synergistic combination of local within-lineage effects and differential

543 extinction patterns strongly influenced Triassic Lilliput faunas, weakening the hypothesized role

544 of rapid adaptive evolution of new small-bodied forms. Similar within-lineage size decreases and

545 size selective extinctions contributed strongly to Lilliput patterns in marine gastropods, 
546 foraminifera, and brachiopods, although all three mechanisms have been invoked to explain Early

547 Triassic foraminifera size distributions globally (Payne, 2005; Metcalfe, Twitchett \& Price-Lloyd, 548 2011; Song, Tong \& Chen, 2011; Rego et al., 2012). Contrary to the present results, growth mark

549 analyses on lingulid brachiopods are suggestive of different physical factors influencing skeletal

550 growth in marine benthos (due to slowed, but prolonged shell secretion over many years)

551 (Metcalfe, Twitchett \& Price-Lloyd, 2011). More skeletochronologic and phylogenetic data are

552 needed, however, to understand the generality of these patterns among Permo-Triassic Lilliput

553 taxa in marine and terrestrial realms.

554 Although some effects on size and growth are observable in Triassic therocephalians (and

555 perhaps therapsids more generally), it is important to note that much of the diversity observed in

556 the earliest Triassic Lystrosaurus Assemblage Zone of the Karoo originated during the Late

557 Permian, and that variation in body sizes and growth patterns during the Late Permian was

558 supplanted by increased bimodality in the Early Triassic Lystrosaurus AZ: small-to-medium, fast-

559 growing akidnognathids and the still smaller, slower-growing baurioids. Small size and short

560 growth duration were dominant life history strategies of Early Triassic therocephalians in the

561 Karoo, and reductions in size were typically associated with lesser tissue vascularity and growth

562 rates across but not within taxa. Furthermore, although these strategies were apparently common

563 in the post-extinction environment, their success was temporary. Low rates of origination in

564 therocephalians during this time, coupled with small sizes and reduced niche occupation may

565 have afforded the opportunity for more marginalized groups to diversify (e.g., cynodonts and

566 archosauromorphs). Future applications of phylogenetic comparative methods to studies of body

567 size and growth during the Permo-Triassic will enhance our understanding of interplay between

568 macroevolution and extinctions, and will identify areas of phylogeny that correspond to shifts in

569 trait evolution that conferred success on lineages. 


\section{Acknowledgments}

572 AKH thanks S. Herring, E. Nesbitt, C. Sidor, and G. Wilson for providing helpful suggestions on

573 the project. F. Abdala and B. Rubidge (BP), E. Butler (NMQR), E. De Kock and J. Neveling

574 (CGS), P. Holroyd (UCMP), and S. Kaal and R. Smith (SAM) are acknowledged for specimen

575 access. F. Abdala and K. Angielczyk offered additional insights into body size evolution and

576 growth, as well as therapsid diversity patterns during the end-Permian extinction. The National

577 Museum preparatory staff also provided assistance and preparation of some specimens for

578 histological processing: J. Nyaphuli, J. Mohoi, N. Ntheri, S. Stuurman, S. Ledibane, S. Chaka,

579 and W. Molehe. Digital image processing and some histologic preparation performed by J.

580 Lungmus (University of Washington). F. Abdala, A. Crompton, and C. Organ are acknowledged

581 for their kind and constructive reviews of this manuscript.

583 References

584 Abdala F, Rubidge BS, van den Heever J. 2008. The oldest therocephalians (Therapsida, 585 Eutheriodontia) and the early diversification of Therapsida. Palaeontology 51:1011-1024.

586 Angielczyk KD, Walsh ML. 2008. Patterns in the evolution of nares size and secondary palate length

587 in anomodont therapsids (Synapsida): implications for hypoxia as a cause of end-Permian 588 tetrapod extinctions. Journal of Paleontology 82:528-542.

589 Botha J. 2003. Biological aspects of the Permian dicynodont Oudenodon

590 (Therapsida:Dicynodontia) deduced from bone histology and cross-sectional geometry.

$591 \quad$ Palaeontologia Africana 39:37-44.

592 Botha J, Angielczyk K. 2007. An integrative approach to distinguishing the Late Permian

593 dicynodont species Oudenodon baini and Tropidostoma microtrema (Therapsida:

$594 \quad$ Anomodontia). Palaeontology 50:1175-1209.

595 Botha J, Chinsamy A. 2000. Growth patterns deduced from the histology of the cynodonts 
597 Botha J, Chinsamy A. 2004. Growth and lifestyle adaptations of the Triassic non-mammalian cynodont Trirachodon. Acta Palaeontologica Polonica 49:619-627.

599 Botha J, Chinsamy A. 2005. Growth patterns of Thrinaxodon, a non-mammalian cynodont from the $600 \quad$ Early Triassic of South Africa. Palaeontology 48:385-394.

601 Botha J, Smith RMH. 2006. Rapid vertebrate recuperation in the Karoo Basin of South Africa 602 following the end-Permian extinction. Journal of African Earth Sciences 45:502-514.

603 Botha-Brink J, Abdala F, Chinsamy A. 2012. The radiation and osteohistology of nonmammaliaform cynodonts. Forerunners of Mammals: Radiation, Histology, Biology, Indiana University Press, Bloomington, ed Chinsamy-Turan A, pp. 223-246.

Botha-Brink J, Angielczyk K. 2010. Do extraordinarily high growth rates in Permo-Triassic dicynodonts (Therapsida, Anomodontia) explain their success before and after the endPermian extinction? Zoological Journal of the Linnean Society 160:341-365.

Botha-Brink J, Smith RMH. 2012. Osteohistology of the Triassic archosauromorphs Prolacerta, Proterosuchus, Euparkeria, and Erythrosuchus from the Karoo Basin of South Africa. Journal of Vertebrate Paleontology 31:1238-1254.

612 Buffrénil V de, Houssaye A, Böhme W. 2007. Bone vascular supply in monitor lizards (Squamata:

613 Varanidae): implications of size, growth, and phylogeny. Journal of Morphology 269:533614 543.

Calder WA III. 1984. Size, Function, and Life History. Harvard University Press, Cambridge: 431 pp.

615 Case TJ. 1978. On the evolution and adaptive significance of postnatal growth rates in the 616 terrestrial vertebrates. The Quarterly Review of Biology 53:243-282.

Castanet J, Curry Rogers K, Cubo J, Boisard J-J. 2000. Periosteal bone growth rates in extant ratites (ostrich and emu): implications for assessing growth in dinosaurs. Comptes Rendus de l'Académie des Sciences de Paris, Science de la Vie 323:543-550. 
617 Chinsamy A. 1993. Bone histology and growth trajectory of the prosauropod dinosaur

618 Massospondylus carinatus Owen. Modern Geology 18:319-329.

619 Chinsamy A, Abdala F. 2008. Paleobiological implications of the bone microstructure of South

620 American traversodontids (Therapsida: Cynodontia). South African Journal of Science

$621 \quad 104: 225-230$.

622 Chinsamy A, Hurum J. 2006. Bone microstructure and growth patterns of early mammals. Acta 623 Palaeontologica Polonica 51:325-338.

624 Chinsamy A, Raath M. 1992. Preparation of fossil bone for histological examination. Palaeontologia $625 \quad$ Africana 29:39-44.

626 Chinsamy A, Rubidge BS. 1993. Dicynodont (Therapsida) bone histology: Phylogenetic and physiological implications. Palaeontologia Africana 30:97-102.

Chinsamy-Turan A. 2012. Forerunners of Mammals: Radiation, Histology, Biology. Indiana University Press, Bloomington.

628 Chinsamy-Turan A, Ray S. 2012. Bone histology of some therocephalians and gorgonopsians, and 629 evidence of bone degradation by fungi. Forerunners of Mammals: Radiation, Histology, Biology, Indiana University Press, Bloomington, ed Chinsamy-Turan A, pp. 199-221.

631 Cormack D. 1987. Ham’s Histology. Lippincott, New York, 732 pp.

632 Cubo J, Le Roy N, Martinez-Maza C, Montes L. 2012. Paleohistological estimation of bone 633 growth rate in extinct archosaurs. Paleobiology 38:335-349.

634 Currey JD. 1987. The evolution of the mechanical properties of amniote bone. Journal of $635 \quad$ Biomechanics 20:1035-1044.

636 Currey JD. 2002. Bones: Structure and Mechanics, 2nd ed. Princeton University Press, Princeton, $637 \quad$ N.J.

638 Currey JD, Alexander RMcN. 1985. The thickness of the walls of tubular bones. Journal of Zoology 639 206:453-468. 
640 Díaz-Uriarte R, Garland T. 1996. Testing hypotheses of correlated evolution using

641 phylogenetically independent contrasts: sensitivity to deviations from Brownian motion.

$642 \quad$ Systematic Biology 45:27-47.

643 Enlow DH. 1969. The bone of reptiles. Biology of the Reptilia, Volume 1: Morphology A,

644 Academic Press, London, eds Gans C, Bellairs A, \& Parsons T, pp. 45-77.

645 Enlow DH, Brown SO. 1957. A comparative histological study of fossil and Recent bone tissues, Part

646 II. Texas Journal of Science 9:186-214.

647 Erickson GM, Makovicky PJ, Currie PJ, Norell MA, Yerby SA, Brochu CA. 2004. Gigantism and

648 comparative life-history parameters of tyrannosaurid dinosaurs. Nature 430:772-775.

649 Felsenstein J. 1985. Phylogenies and the comparative method. American Naturalist 125:1-15.

650 Fourie H, Rubidge BS. 2007. The postcranial skeletal anatomy of the therocephalian Regisaurus

651 (Therapsida: Regisauridae) and its utilization for biostratigraphic correlation.

652 Palaeontologia Africana 42:1-16.

653 Fourie H, Rubidge BS. 2009. The postcranial skeleton of the basal therocephalian Glanosuchus

654 macrops (Scylacosauridae) and comparison of morphological and phylogenetic trends

655 amongst the Theriodontia. Palaeontologia Africana 44:27-39.

656 Garland T, Bennett AF, Rezende EL. 2005. Phylogenetic approaches in comparative physiology.

657 Journal of Experimental Biology 208:3015-3035.

658 Germain D, Laurin M. 2005. Microanatomy of the radius and lifestyle in amniotes (Vertebrata, 659 Tetrapoda). Zoologica Scripta 34:335-350.

660 Gould SJ. 1977. Ontogeny and Phylogeny. Belknap Press of Harvard University Press, Cambridge.

661 Green JL, Schweitzer MH, Lamm E-T. 2010. Limb bone histology and growth in Placerias

662 hesternus (Therapsida: Anomodontia) from the Upper Triassic of North America.

$663 \quad$ Palaeontology 53:347-364.

664 Harries PJ, Kauffman EG, Hansen TA. 1996. Models of biotic survival following mass extinction. 
667 Harries PJ, Knorr PO. 2009. What does the 'Lilliput Effect' mean? Palaeogeography,

668 Palaeoclimatology, and Palaeoecology 284:4-10.

669 Huttenlocker AK. 2009. An investigation into the cladistic relationships and monophyly of 670 therocephalian therapsids (Amniota: Synapsida). Zoological Journal of the Linnean $671 \quad$ Society $157: 865-891$.

672 Huttenlocker AK. 2013. The Paleobiology of South African Therocephalian Therapsids (Amniota, Synapsida) and the Effects of the End-Permian Extinction on Size, Growth, and Bone Microstructure. Unpublished $\mathrm{PhD}$ dissertation. University of Washington, Seattle.

Huttenlocker AK. 2014. Body size reductions in nonmammalian eutheriodont therapsids (Synapsida) during the endPermian mass extinction. PLOS:ONE. DOI: 10.1371/journal.pone.0087553

Huttenlocker AK, Botha-Brink J. 2013. Body size and growth patterns in the therocephalian Moschorhinus kitchingi (Therapsida: Eutheriodontia) before and after the end-Permian extinction in South Africa. Paleobiology $39: 253-277$.

676 Huttenlocker AK, Mazierski D, Reisz R. 2011. Comparative osteohistology of hyperelongate neural spines in the Edaphosauridae (Amniota: Synapsida). Palaeontology 54:573-590.

678 Huttenlocker AK, Rega E. 2012. The paleobiology and bone microstructure of pelycosauriangrade synapsids. Forerunners of Mammals: Radiation, Histology, Biology, Indiana

681 Huttenlocker AK, Rega E, and Sumida SS. 2010. Comparative anatomy and osteohistology of 682 hyperelongate neural spines in the sphenacodontids Sphenacodon and Dimetrodon 683 (Amniota: Synapsida). Journal of Morphology 271:1407-1421.

684 Huttenlocker AK, Sidor CA, Smith RMH. 2011. A new specimen of Promoschorhynchus 

and its implications for theriodont survivorship across the Permo-Triassic boundary. Journal of Vertebrate Paleontology 31:405-421.

688 Huttenlocker, A., H. N. Woodward, B. K. Hall. 2013. Chapter 2: Biology of Bone. Bone Histology of Fossil Tetrapods: Advancing Methods, Analysis, and Interpretation, University of California Press, Berkeley, eds Padian K \& Lamm E-T, pp. 12-34.

691 Jasinoski SC, Rayfield EJ, Chinsamy A. 2010. Functional implications of dicynodont cranial 692 suture morphology. Journal of Morphology 271:705-728. Transactions of the Royal Society of London: Series B 264:1-54.

Kemp TS. 1972a. Whaitsiid Therocephalia and the origin of cynodonts. Philosophical

Kemp TS. 1972b. The jaw articulation and musculature of the whaitsiid Therocephalia. Studies in Vertebrate Evolution, Winchester Press, New York, eds Joysey KA \& Kemp TS, pp. 213230. Journal of Zoology 186:143-161.

Kemp TS. 1986. The skeleton of a baurioid therocephalian therapsid from the Lower Triassic (Lystrosaurus Zone) of South Africa. Journal of Vertebrate Paleontology 6:215-232.

702 Kriloff A, Germain D, Canoville A, Vincent P, Sache M, Laurin M. 2008. Evolution of bone microanatomy of the tetrapod tibia and its use in paleobiological inference. Journal of Evolutionary Biology 21:807-826.

Laurin M, Girondot M, Loth M. 2004. The evolution of long bone microstructure and lifestyle in lissamphibians. Paleobiology 30:589-613. Berkeley: 210 pp. 
710 Lee AH, Huttenlocker AK, Padian K, Woodward HN. 2013. Chapter 8: Analysis of growth rates.

711 Bone Histology of Fossil Tetrapods: Advancing Methods, Analysis, and Interpretation,

712 University of California Press, Berkeley, eds Padian K \& Lamm E-T, pp. 209-243.

Luo G, Lai X, Shi GR, Jiang H, Yin H, Xie S, Tong J, Zhang K, He W, Wignall PB. 2008. Size variation of conodont elements of the Hindeodus-Isarcicella clade during the Permian-Triassic transition in South China and its implications for mass extinction. Palaeogeography, Palaeoclimatology, Palaeoecology 264:176-187.

Maddison WP, Maddison DR. 2007. Mesquite: a modular system for evolutionary analysis. Version 2.0. http://mesquiteproject.org

713 Margerie E de, Cubo J, Castanet J. 2002. Bone typology and growth rate: testing and quantifying

714 'Amprino's rule' in the mallard (Anas platyrhynchos). Comptes Rendus Biologies

$715 \quad 325: 221-230$.

Margerie E de, Robin J-P, Verrier D, Cubo J, Groscolas R, Castanet J. 2004. Assessing a relationship between bone microstructure and growth rate: a fluorescent labeling study in the king penguin chick (Aptenodytes patagonicus). Journal of Experimental Biology 207:869-879.

716 Metcalfe B, Twitchett RJ, Price-Lloyd N. 2011. Size and growth rate of 'Lilliput' animals in the 717 earliest Triassic. Palaeogeography, Palaeoclimatology, Palaeoecology 308:171-180.

718 Midford PE, Garland T, Maddison WP. 2011. PDAP:PDTREE module for Mesquite (version

719 1.16). http://mesquiteproject.org/pdap mesquite/index.html.

720 Mutter RJ, Neuman AG. 2009. Recovery from the end-Permian extinction event: evidence from

721 “Lilliput Listracanthus.” Palaeogeography, Palaeoclimatology, Palaeoecology 284:22-28.

Nasterlack T, Canoville A, Chinsamy-Turan A. 2012. New insights into the biology of the Permian genus Cistecephalus (Therapsida, Dicynodontia). Journal of Vertebrate Paleontology 32:1396-1410.

Payne JL. 2005. Evolutionary dynamics of gastropod size across the end-Permian extinction and through the Triassic recovery interval. Paleobiology 31:269-290.

Peters R. 1983. The Ecological Implications of Body Size. Cambridge University Press, Cambridge: 344 pp.

Rasband WS. ImageJ, U. S. National Institutes of Health, Bethesda, Maryland, USA, http://imagej.nih.gov/ij/, 19972012. 
722 Ray S, Botha J, Chinsamy A. 2004. Bone histology and growth patterns of some nonmammalian 723 therapsids. Journal of Vertebrate Paleontology 24:634-648.

724 Ray S, Chinsamy A, Bandyopadhyay S. 2005. Lystrosaurus murrayi (Therapsida; Dicynodontia):

725 bone histology, growth and lifestyle adaptations. Palaeontology 48:1169-1185.

726 Ray S, Bandyopadhyay S, Bhawal D. Growth patterns as deduced from bone microstructure of

727 some selected neotherapsids with special emphasis on dicynodonts: Phylogenetic

728 implications. Palaeoworld 18:53-66.

729 Ray S, Bandyopadhyay S, Appana R. 2010. Chapter 5: Bone histology of a kannemeyriid dicynodont

730

731 Wadiasaurus: palaeobiological implications. New Aspects of Mesozoic Biodiversity (Lecture Notes in Earth Sciences 132) Springer, Berlin, ed Bandyopadhyay S, pp. 73-89.

732 Ray S, Botha-Brink J, Chinsamy-Turan A. 2012. Dicynodont growth dynamics and lifestyle adaptations. Forerunners of Mammals: Radiation, Histology, Biology, Indiana University Press, Bloomington, ed Chinsamy-Turan A, pp. 121-146.

Ray S, Chinsamy A. 2004. Diictodon feliceps (Therapsida, Dicynodontia): bone histology, growth and biomechanics. Journal of Vertebrate Paleontology 24:180-194.

Rego BL, Wang SC, Altiner D, Payne JL. 2012. Within- and among-genus components of foraminiferan size evolution during mass extinction, recovery, and background intervals. Paleobiology 38:627-643.

Retallack GJ. 2003. Vertebrate extinction across the Permian-Triassic boundary in the Karoo Basin of South Africa. Bulletin of the Geological Society of America 115:1133-1152.

737 Ricqlès A de. 1969. Recherches paléohistologiques sur les os longs des Tétrapodes II-Quelques observations sur la structure des os longs des Thériodontes. Annales de Paléontologie (Vertébrés) 55:1-52. [in French]

741 Ricqlès A de. 1974b. Recherches paléohistologiques sur les os longs des Tétrapodes IVEothériodontes et pélycosaures. Annales de Paléontologie (Vertébrés) 60:3-39. [in 
744 Ricqlès A de. 1976. On bone histology of fossil and living reptiles, with comments on its functional and evolutionary significance. Morphology and Biology of Reptiles, Academic Press, London, eds Bellairs A \& Cox CB, pp.123-150.

Roth, JJ, Roth EC, Hotton N III. 1986. The parietal foramen and eye: their function and fate in therapsids. The Ecology and Biology of Mammal-like Reptiles. Smithsonian Institution Press,

Shelton CD, Sander PM, Stein K, Winkelhorst H. 2013. Long bone histology indicates sympatric species of Dimetrodon (Lower Permian, Sphenacodontidae). Earth and Environmental Science Transactions of the Royal Society of Edinburgh 103:1-20.

Sigurdsen T. 2006. New features of the snout and orbit of a therocephalian therapsid from South Africa. Acta Palaeontologica Polonica 51:63-75.

Sigurdsen T, Huttenlocker AK, Modesto SP, Rowe T, Damiani R. 2012. Reassessment of the morphology and paleobiology of the therocephalian Tetracynodon darti (Therapsida), and the phylogenetic relationships of Baurioidea. Journal of Vertebrate Paleontology 32:1113-1134.

755 Smith RMH, Botha J. 2005. The recovery of terrestrial vertebrate diversity in the South African Karoo Basin after the end-Permian extinction. Comptes Rendus Palevol 4:623-636.

Song H, Tong J, Chen ZQ. 2011. Evolutionary dynamics of the Permian-Triassic foraminifer size: Evidence for Lilliput effect in the end-Permian mass extinction and its aftermath. Palaeogeography, Palaeoclimatology, Palaeoecology 308:98-110.

Stearns SC. 1992. The Evolution of Life Histories. Oxford University Press, Oxford: 249 pp.

757 Stein K, Prondvai E. 2013. Rethinking the nature of fibrolamellar bone: an integrative biological revision of sauropod plexiform bone formation. Biological Reviews of the Cambridge

760 Thomason JJ, Russell AP. 1986. Mechanical factors in the evolution of the mammalian secondary palate: a theoretical analysis. Journal of Morphology 189:199-213. 
762 Twitchett RJ. 2007. The Lilliput effect in the aftermath of the end-Permian extinction event. Palaeogeography, Palaeoclimatology, Palaeoecology 252:132-144.

764 Twitchett RJ, Barras CG. 2004. Trace fossils in the aftermath of mass extinction events. The

765

766

767

768 769

\section{Paleontology 57:197-207.}

Wall PW. 1983. The correlation between high limb-bone density and aquatic habitats in recent mammals. Journal of

770

771

772

773

774

775

776

777

778

779

780

781

782

783

784 Application of Ichnology to Palaeoenvironmental and Stratigraphic Analysis, Geological Society Special Publications 228, Geological Society of London, London, ed McIlroy D, pp. $397-418$

Urbanek A. 1993. Biotic crises in the history of Upper Silurian graptoloids: a paleobiological model. Historical Biology 7:29-50.

Wilson JW. 1994. Histological techniques. Vertebrate Paleontological Techniques Cambridge University Press, New York, ed Leiggi P \& May P, pp. 205-234.

3


Appendix 1. List of institutional abbreviations.

BP, Evolutionary Studies Institute (previously Bernard Price Institute for Palaeontological Paleontology, Berkeley.

\section{Tables \& Figure Captions}

Table 2. Pearson's product-moment correlation statistics (Pearson's $r$ and $p$ ) for size, robusticity, and vascular growth proxies in therocephalians.

808 Figure 1. Stratigraphic ranges of therocephalians sampled histologically in the present study.

809 Dashed line indicates position of Permian-Triassic Boundary (PTB). Abbreviations: Chx,

810 Changxingian; Cisteceph AZ, Cistecephalus Assemblage Zone; Cyn sub A, Cynognathus subzone

811 A; Eodicyno AZ, Eodicynodon Assemblage Zone; Ind, Induan; Olen, Olenekian; Pristerog AZ,

812 Pristerognathus Assemblage Zone; Roa, Roadian; Tapinoceph AZ, Tapinocephalus Assemblage

813 Zone; Tropido AZ, Tropidostoma Assemblage Zone; Wor, Wordian. 
821 Figure 2. Bone microstructure in selected basal therocephalians and Permo-Triassic

822 eutherocephalians. A, Middle Permian Lycosuchus (SAM-PK-K9012), femur midshaft, dorsal 823 cortex showing subplexiform fibrolamellar bone viewed under non-polarized light. B, Middle 824 Permian Lycosuchus (SAM-PK-9084), ulna midshaft, cortical fibrolamellar bone viewed at high 825 magnification showing reticular canals in a woven-fibered matrix (crossed-nicols with wave 826 plate). C, Scylacosauridae indet. (CGS R300), humerus midshaft, cortex viewed at low magnification showing growth marks (crossed-nicols with wave plate). D, Early Triassic

828 akidnognathid Olivierosuchus (NMQR 3605), humerus midshaft, cortical fibrolamellar bone 829 showing thick zone of reticular fibrolamellar bone followed by parallel-fibered bone and a LAG 830 (crossed-nicols with wave plate). E, Olivierosuchus (SAM-PK-K10617), femur midshaft, close831 up of primary osteons and woven-fibered interstitial matrix (crossed-nicols with wave plate). F, 832 Late Permian hofmeyriid Mirotenthes (SAM-PK-K6511), femur midshaft, cortical parallel833 fibered bone showing annular growth marks (crossed-nicols with wave plate). G, Late Permian 834 whaitsiid Theriognathus (NMQR 3375), femur midshaft, cortical fibrolamellar bone viewed at 835 medium magnification showing growth marks (non-polarized light). Arrows denote growth 836 marks. Detailed descriptions and photomicrographs are provided in the Supporting Data file. 837 Abbreviations: pfb, parallel-fibered bone; po, primary osteon; re, reticular fibrolamellar bone.

839 Figure 3. Bone microstructure in selected Permo-Triassic baurioid eutherocephalians. A, Late

840 Permian Ictidosuchoides subadult (SAM-PK-8659), radius midshaft, cortex and inner cancellous

841 bony scaffold (crossed-nicols with wave plate). B, Ictidosuchoides adult (BP/1/4092), humerus

842 midshaft, cortex with longitudinal and reticular primary osteons and growth marks (crossed-

843 nicols with wave plate). C, Early Triassic Tetracynodon (NMQR 3745), humerus midshaft, cortex

844 showing inner fibrolamellar bone and sparsely vascularized outer parallel-fibered bone (crossed-

845 nicols with wave plate). D, Early Triassic Scaloposaurus (SAM-PK-K4638), humerus midshaft, 846 cortex showing longitudinal and reticular fibrolamellar bone deposition followed by a thin collar 847 of lamellar bone in the subperiosteal region (crossed-nicols with wave plate). E, Middle Triassic 
bauriid Microgomphodon (NMQR 3605), humerus midshaft, cortex showing reticular fibrolamellar bone with no growth marks (crossed-nicols with wave plate). F, Microgomphodon (NMQR 3605), femur midshaft, cortex showing reticular fibrolamellar bone (crossed-nicols with wave plate). Arrows denote growth marks. Detailed descriptions and photomicrographs are provided in the Supporting Data file. Abbreviations: pfb, parallel-fibered bone; re, reticular fibrolamellar bone.

Figure 4. Linear regression of vascular growth proxies against size (midshaft cross-sectional area) from limb bone elements. A, Mean cortical vascularity $(\% \mathrm{CV})$ against midshaft crosssectional area. B, Mean primary osteon diameter $(P O D)$ against midshaft cross-sectional area. $\mathbf{C}$, mean \% $\mathrm{CV}$ against mean $P O D$. All correlations between vascular growth proxies and size are strongly positively correlated for both propodials (solid regression line) and epipodials (dashed regression line) (see statistical results in Table 2). Blue circles $=$ propodials. Red circles $=$ epipodials.

Figure 5. Comparison of bone histology and microvasculature in Permian Theriognathus and Moschorhinus. A, Theriognathus (NMQR 3375) femur midshaft cortex (non-polarized light). B, Moschorhinus (NMQR 3939) humerus midshaft cortex (non-polarized light). Note the greater overall degree of vascularity in 'B.'

Figure 6. Mirror phylogenies of Permo-Triassic therocephalians sampled for bone histology (scaled to geologic time). Phylogenetic character mapping of histological traits estimated from propodials (left) and epidpodials (right) reveals comparable ancestor-descendant changes for each pool of skeletal elements. A, average cortical vascularity $(\% \mathrm{CV})$. $\mathbf{B}$, average primary osteon diameter $(P O D)$. $\mathbf{C}$, relative bone wall thickness $(R B T)$. Ancestral states were reconstructed using squared-change parsimony in Mesquite version 2.0 (Maddison and Maddison, 2007).

Figure 7. Summary of evolution of size and bone microstructural traits. Black bars represent stratigraphic ranges of taxa that were sampled histologically. Numbers in parentheses to right of black bars denote maximum size of taxon in interval of first appearance. Tree topology and ranges from Huttenlocker, 2013 and 2014. In graph at top of figure, circles represent average 
$880 \% \mathrm{CV}$ and squares average POD of propodials (blue) and epipodials (red). Abbreviations: Chx, 881 Changxingian; Cisteceph AZ, Cistecephalus Assemblage Zone; Cyn sub A, Cynognathus subzone 882 A; Eodicyno AZ, Eodicynodon Assemblage Zone; Ind, Induan; Olen, Olenekian; Pristerog AZ, 883 Pristerognathus Assemblage Zone; Roa, Roadian; Tapinoceph AZ, Tapinocephalus Assemblage 884 Zone; Tropido AZ, Tropidostoma Assemblage Zone; Wor, Wordian. 


\section{Table 1 (on next page)}

Specimens, elements, and histometric measurements in studied therocephalians. 
Table 1. Specimens, elements, and histometric measurements in studied therocephalians.

$\begin{array}{llllll}\text { \% Largest* Element } & \begin{array}{l}\text { Midshaft cross- } \\ \text { sectional area } \\ \left(\mathrm{mm}^{2}\right)\end{array} & \begin{array}{l}R B T \\ (\%)\end{array} & & \begin{array}{l}\text { Cortical } \\ \text { vascularity } \\ (\%)\end{array} & \text { POD }(\mu \mathrm{m}) \\ & & & (\%)\end{array}$

\begin{tabular}{|c|c|c|c|c|c|c|c|}
\hline \multicolumn{8}{|l|}{ Lycosuchus } \\
\hline \multirow[t]{2}{*}{ SAM-PK-9084 } & \multirow[t]{2}{*}{$100 \%$} & radius & 296.76 & 16 & 0.42 & $10.7[5.5]$ & $101[11]$ \\
\hline & & ulna & 325.40 & 25 & 0.38 & $15.7[2.0]$ & $109[26]$ \\
\hline SAM-PK-K9012 & -- & femur & 1276.60 & 15 & 0.67 & $16.9[6.2]$ & $168[17]$ \\
\hline \multicolumn{8}{|l|}{ Glanosuchus } \\
\hline $\mathrm{BP} / 1 / 6228$ & $47 \%$ & ulna & 57.62 & 20 & 0.42 & $04.9[0.9]$ & $51[13]$ \\
\hline \multicolumn{8}{|c|}{ Scylacosauridae indet. } \\
\hline \multirow[t]{2}{*}{$\mathrm{BP} / 1 / 5576$} & -- & radius & 30.99 & 19 & 0.47 & $10.3[2.2]$ & $68[10]$ \\
\hline & & ulna & 36.63 & 24 & 0.53 & $09.7[4.3]$ & $71[08]$ \\
\hline \multirow[t]{3}{*}{$\mathrm{BP} / 1 / 5587$} & -- & humerus & 169.42 & 33 & 0.29 & $13.3[3.2]$ & $75[08]$ \\
\hline & & radius & 88.26 & 23 & 0.46 & $03.5[0.7]$ & $71[15]$ \\
\hline & & ulna & 120.25 & 24 & 0.44 & $06.0[0.8]$ & $85[07]$ \\
\hline CGS R300 & -- & humerus & 308.56 & 31 & 0.32 & $15.9[6.5]$ & $112[13]$ \\
\hline \multirow[t]{5}{*}{ SAM-PK-5018 } & -- & humerus & - & - & -- & - & -- \\
\hline & & radius & - & 17 & -- & - & -- \\
\hline & & femur & - & 15 & -- & - & -- \\
\hline & & tibia & 83.86 & 24 & 0.60 & $10.3[1.5]$ & $55[10]$ \\
\hline & & fibula & -- & -- & -- & - & -- \\
\hline SAM-PK-11557 & -- & fibula & 49.10 & 25 & 0.47 & $07.0[2.8]$ & $44[07]$ \\
\hline \multicolumn{8}{|l|}{ Moschorhinus } \\
\hline \multirow[t]{4}{*}{ NMQR 48} & $62 \%$ & humerus & 205.85 & 30 & 0.45 & $16.6[5.0]$ & -- \\
\hline & & radius & 48.10 & 26 & 0.40 & $05.2[2.4]$ & 67[18] \\
\hline & & ulna & 102.67 & 27 & 0.43 & $04.8[1.3]$ & $67[10]$ \\
\hline & & femur & 263.13 & 22 & 0.58 & $12.8[4.8]$ & $95[13]$ \\
\hline \multirow[t]{6}{*}{ NMQR 3939} & $65 \%$ & humerus & 212.25 & 35 & 0.38 & $20.1[6.9]$ & $134[36]$ \\
\hline & & radius & 92.77 & 34 & 0.31 & $11.4[2.6]$ & $101[18]$ \\
\hline & & ulna & 101.86 & 29 & 0.44 & $10.1[2.1]$ & $120[27]$ \\
\hline & & femur & 206.82 & 28 & 0.44 & $18.4[6.9]$ & $140[32]$ \\
\hline & & tibia (1) & 103.85 & 37 & 0.30 & $15.5[1.9]$ & $117[17]$ \\
\hline & & tibia (r) & 114.28 & 31 & 0.39 & $15.6[5.8]$ & $119[34]$ \\
\hline NMQR 1640a & $(84 \%)$ & femur & 325.70 & 25 & 0.50 & $11.1[4.8]$ & $96[12]$ \\
\hline NMQR $1640 \mathrm{~b}$ & - & tibia & 427.87 & 35 & 0.39 & $09.7[2.5]$ & $106[23]$ \\
\hline NMQR 3351 & $91 \%$ & femur & 488.65 & 21 & 0.55 & $13.6[5.0]$ & $100[22]$ \\
\hline NMQR 3684 & $(95 \%)$ & femur & 378.12 & 27 & 0.53 & $14.2[4.6]$ & $92[17]$ \\
\hline \multirow[t]{2}{*}{ SAM-PK-K118 } & $59 \%$ & humerus & 161.60 & 28 & 0.41 & $25.5[4.9]$ & $100[17]$ \\
\hline & & radius & 62.80 & 23 & 0.54 & $19.5[3.2]$ & $101[17]$ \\
\hline SAM-PK-K9953 & $59 \%$ & femur & 155.13 & 25 & 0.42 & $20.9[5.8]$ & $108[15]$ \\
\hline \multirow[t]{3}{*}{ UCMP 42787} & $(67 \%)$ & humerus & 209.64 & 35 & 0.34 & $19.5[4.0]$ & $107[20]$ \\
\hline & & radius & 83.64 & 35 & 0.27 & $12.4[3.6]$ & $92[18]$ \\
\hline & & fibula & 42.53 & 32 & 0.28 & $10.8[1.9]$ & $58[14]$ \\
\hline \multirow[t]{3}{*}{$\mathrm{BP} / 1 / 4227$} & $76 \%$ & humerus & 312.00 & 33 & 0.35 & $12.1[2.9]$ & $100[16]$ \\
\hline & & radius & 103.60 & 30 & 0.36 & $10.9[2.1]$ & $88[10]$ \\
\hline & & ulna & 96.00 & 26 & 0.48 & $08.5[2.0]$ & 91 [19] \\
\hline
\end{tabular}


Table 1. (Continued)

\begin{tabular}{|c|c|c|c|c|c|c|c|}
\hline \multicolumn{8}{|l|}{ Olivierosuchus } \\
\hline NMQR 3605 & $100 \%$ & humerus & 47.54 & 36 & 0.38 & $09.9[1.8]$ & $99[10]$ \\
\hline SAM-PK-K10617 & $(65 \%)$ & femur & 23.72 & 19 & 0.65 & $03.4[1.1]$ & $75[10]$ \\
\hline \multicolumn{8}{|l|}{ Hofmeyria } \\
\hline \multirow[t]{5}{*}{ BP/1/4404 } & $69 \%$ & humerus & 12.56 & 31 & 0.32 & $07.5[1.4]$ & $72[11]$ \\
\hline & & radius (1) & 4.80 & 35 & 0.26 & $03.4[1.0]$ & $46[05]$ \\
\hline & & radius $(\mathrm{r})$ & 4.04 & 40 & 0.15 & $04.8[1.9]$ & $47[05]$ \\
\hline & & ulna (1) & 3.63 & 39 & 0.22 & $03.0[0.6]$ & $39[05]$ \\
\hline & & ulna (r) & 4.30 & 39 & 0.20 & $04.7[1.1]$ & $43[08]$ \\
\hline \multicolumn{8}{|l|}{ Mirotenthes } \\
\hline \multirow[t]{6}{*}{ SAM-PK-K6511 } & $78 \%$ & humerus & 17.12 & 32 & 0.31 & $05.4[1.5]$ & $54[07]$ \\
\hline & & radius & 6.28 & 34 & 0.33 & $03.5[1.5]$ & 38 [07] \\
\hline & & ulna & 5.24 & 32 & 0.42 & $02.0[0.5]$ & $41[07]$ \\
\hline & & femur & 19.40 & 25 & 0.42 & $03.6[0.6]$ & $58[07]$ \\
\hline & & tibia & 11.28 & 31 & 0.31 & $03.1[0.8]$ & $38[06]$ \\
\hline & & fibula & 3.64 & 32 & 0.39 & $03.9[1.1]$ & $32[04]$ \\
\hline \multicolumn{8}{|l|}{ Theriognathus } \\
\hline NMQR 3375 & $38 \%$ & femur & 43.45 & 24 & 0.51 & $06.2[2.0]$ & $65[10]$ \\
\hline BP/1/719 & $(62 \%)$ & femur & 140.21 & 20 & 0.59 & $06.8[1.4]$ & $87[11]$ \\
\hline \multicolumn{8}{|l|}{ Ictidosuchoides } \\
\hline \multirow[t]{5}{*}{ SAM-PK-K8659 } & $50 \%$ & humerus & 23.92 & 22 & 0.56 & $07.3[2.0]$ & $45[05]$ \\
\hline & & radius & 10.08 & 24 & 0.52 & $04.2[1.1]$ & $38[05]$ \\
\hline & & femur & 45.64 & -- & -- & -- & $38[05]$ \\
\hline & & tibia & 28.32 & 16 & 0.63 & $02.8[1.0]$ & $43[08]$ \\
\hline & & fibula & 10.44 & 22 & 0.59 & $03.8[1.5]$ & $40[07]$ \\
\hline \multirow[t]{3}{*}{ SAM-PK-K10423 } & $(50 \%)$ & femur & 34.80 & 14 & 0.71 & $04.7[1.8]$ & $65[08]$ \\
\hline & & tibia & 9.52 & 23 & 0.49 & $04.3[1.5]$ & $39[05]$ \\
\hline & & fibula & 19.60 & 19 & 0.47 & $04.7[1.6]$ & $40[08]$ \\
\hline BP $/ 1 / 75$ & -- & humerus & 44.27 & 19 & 0.64 & $11.1[1.4]$ & $52[06]$ \\
\hline \multirow[t]{3}{*}{ BP $/ 1 / 4092$} & $100 \%$ & humerus & 60.19 & 22 & 0.56 & $10.2[2.1]$ & $60[07]$ \\
\hline & & radius & 39.52 & 21 & 0.58 & $11.1[3.1]$ & $62[08]$ \\
\hline & & ulna & 74.67 & 26 & 0.54 & $08.3[2.1]$ & $52[08]$ \\
\hline \multicolumn{8}{|l|}{ Tetracynodon } \\
\hline NMQR 3745 & $85 \%$ & humerus & 11.44 & 22 & 0.56 & $8.1[3.2]$ & $36[10]$ \\
\hline \multirow[t]{5}{*}{ UCMP 78395} & (94\%) & humerus & 16.48 & 24 & 0.49 & $4.9[1.7]$ & $42[05]$ \\
\hline & & radius & 8.40 & 27 & 0.43 & $1.9[0.5]$ & $42[10]$ \\
\hline & & ulna & 6.12 & 31 & 0.33 & $2.8[1.0]$ & $38[06]$ \\
\hline & & femur & 18.28 & 17 & 0.66 & $5.0[2.5]$ & $39[06]$ \\
\hline & & tibia & 12.48 & 25 & 0.48 & $3.9[0.7]$ & $42[06]$ \\
\hline \multirow[t]{3}{*}{ UCMP 78396} & (94\%) & humerus & 16.96 & 21 & 0.54 & $4.7[1.9]$ & $42[12]$ \\
\hline & & femur & 18.16 & 17 & 0.62 & $4.3[1.1]$ & $42[07]$ \\
\hline & & fibula & 5.19 & 25 & 0.53 & $2.3[0.5]$ & $35[06]$ \\
\hline \multicolumn{8}{|l|}{ Scaloposaurus } \\
\hline SAM-PK-K4638 & $67 \%$ & humerus & 15.34 & -- & -- & $06.6[1.6]$ & $62[08]$ \\
\hline
\end{tabular}


Table 1. (Continued)

\begin{tabular}{cclccccc}
$\begin{array}{c}\text { Microgomphodon } \\
\text { NMQR 3189 }\end{array}$ & $(82 \%)$ & humerus & 11.04 & 21 & 0.61 & $08.8[2.1]$ & $43[08]$ \\
& & femur & 16.52 & 18 & 0.61 & $06.1[1.6]$ & $44[08]$ \\
& & tibia & 7.86 & 24 & 0.51 & $08.0[3.2]$ & $41[09]$ \\
& & fibula & 3.33 & 29 & 0.39 & $04.2[0.9]$ & $32[04]$ \\
\hline
\end{tabular}

${ }^{*}$ Based on relative basal skull length (BSL). Parentheses indicate estimates for incomplete skulls. 


\section{Table 2 (on next page)}

Pearson's product-moment correlation statistics (Pearson's $r$ and $p$ ) for size, robusticity, and vascular growth proxies in therocephalians. 
Table 2. Pearson's product-moment correlation statistics (Pearson's $r$ and $p$ ) for size, robusticity, and vascular growth proxies in therocephalians.

\begin{tabular}{|c|c|c|c|c|c|c|}
\hline & Propodi & al-only & Epipodi & al-only & Poole & \\
\hline & $r$ & $p^{*}$ & $r$ & $p$ & $r$ & $p$ \\
\hline All therocephalians, raw data & & & & & & \\
\hline In midshaft area vs. RBT & 0.309 & 0.109 & -0.186 & 0.267 & -0.126 & 0.301 \\
\hline In midshaft area vs. $\% C V$ & 0.744 & $<0.001$ & 0.714 & $<0.001$ & 0.746 & $<0.001$ \\
\hline In midshaft area vs. $P O D$ & 0.853 & $<0.001$ & 0.847 & $<0.001$ & 0.850 & $<0.001$ \\
\hline RBT vs. \%CV & 0.452 & 0.012 & 0.034 & 0.839 & 0.149 & 0.217 \\
\hline$R B T$ vs. $P O D$ & 0.360 & 0.050 & 0.111 & 0.512 & 0.143 & 0.237 \\
\hline$\% C V$ vs. POD & 0.760 & $<0.001$ & 0.802 & $<0.001$ & 0.796 & $<0.001$ \\
\hline All therocephalians, independent & & & & & & \\
\hline In midshaft area vs. RBT & -0.466 & 0.174 & -0.476 & 0.232 & -- & -- \\
\hline In midshaft area vs. $\% \mathrm{CV}$ & 0.765 & 0.006 & 0.807 & 0.015 & -- & -- \\
\hline In midshaft area vs. $P O D$ & 0.656 & 0.028 & 0.859 & 0.006 & -- & -- \\
\hline RBT vs. \%CV & -0.077 & 0.831 & -0.224 & 0.592 & -- & -- \\
\hline RBT vs. POD & -0.472 & 0.168 & -0.010 & 0.979 & -- & -- \\
\hline$\% C V$ vs. POD & 0.639 & 0.034 & 0.877 & 0.004 & -- & -- \\
\hline
\end{tabular}

${ }^{*} r$ and $p$-values in boldface are significant at $\alpha=0.05$ 


\section{Figure 1}

Stratigraphic ranges of therocephalians sampled histologically in the present study.

Dashed line indicates position of Permian-Triassic Boundary (PTB). Abbreviations: Chx, Changxingian; Cisteceph AZ, Cistecephalus Assemblage Zone; Cyn sub A, Cynognathus subzone A; Eodicyno AZ, Eodicynodon Assemblage Zone; Ind, Induan; Olen, Olenekian; Pristerog AZ, Pristerognathus Assemblage Zone; Roa, Roadian; Tapinoceph AZ, Tapinocephalus Assemblage Zone; Tropido AZ, Tropidostoma Assemblage Zone; Wor, Wordian. 


\section{Figure 2}

Bone microstructure in selected basal therocephalians and Permo-Triassic eutherocephalians.

A, Middle Permian Lycosuchus (SAM-PK-K9012), femur midshaft, dorsal cortex showing subplexiform fibrolamellar bone viewed under non-polarized light. B, Middle Permian Lycosuchus (SAM-PK-9084), ulna midshaft, cortical fibrolamellar bone viewed at high magnification showing reticular canals in a woven-fibered matrix (crossed-nicols with wave plate). C, Scylacosauridae indet. (CGS R300), humerus midshaft, cortex viewed at low magnification showing growth marks (crossed-nicols with wave plate). D, Early Triassic akidnognathid Olivierosuchus (NMQR 3605), humerus midshaft, cortical fibrolamellar bone showing thick zone of reticular fibrolamellar bone followed by parallel-fibered bone and a LAG (crossed-nicols with wave plate). E, Olivierosuchus (SAM-PK-K10617), femur midshaft, close-up of primary osteons and woven-fibered interstitial matrix (crossed-nicols with wave plate). F, Late Permian hofmeyriid Mirotenthes (SAM-PK-K6511), femur midshaft, cortical parallel-fibered bone showing annular growth marks (crossed-nicols with wave plate). G, Late Permian whaitsiid Theriognathus (NMQR 3375), femur midshaft, cortical fibrolamellar bone viewed at medium magnification showing growth marks (non-polarized light). Arrows denote growth marks. Detailed descriptions and photomicrographs are provided in the Supporting Data file. Abbreviations: pfb, parallel-fibered bone; po, primary osteon; re, reticular fibrolamellar bone. 

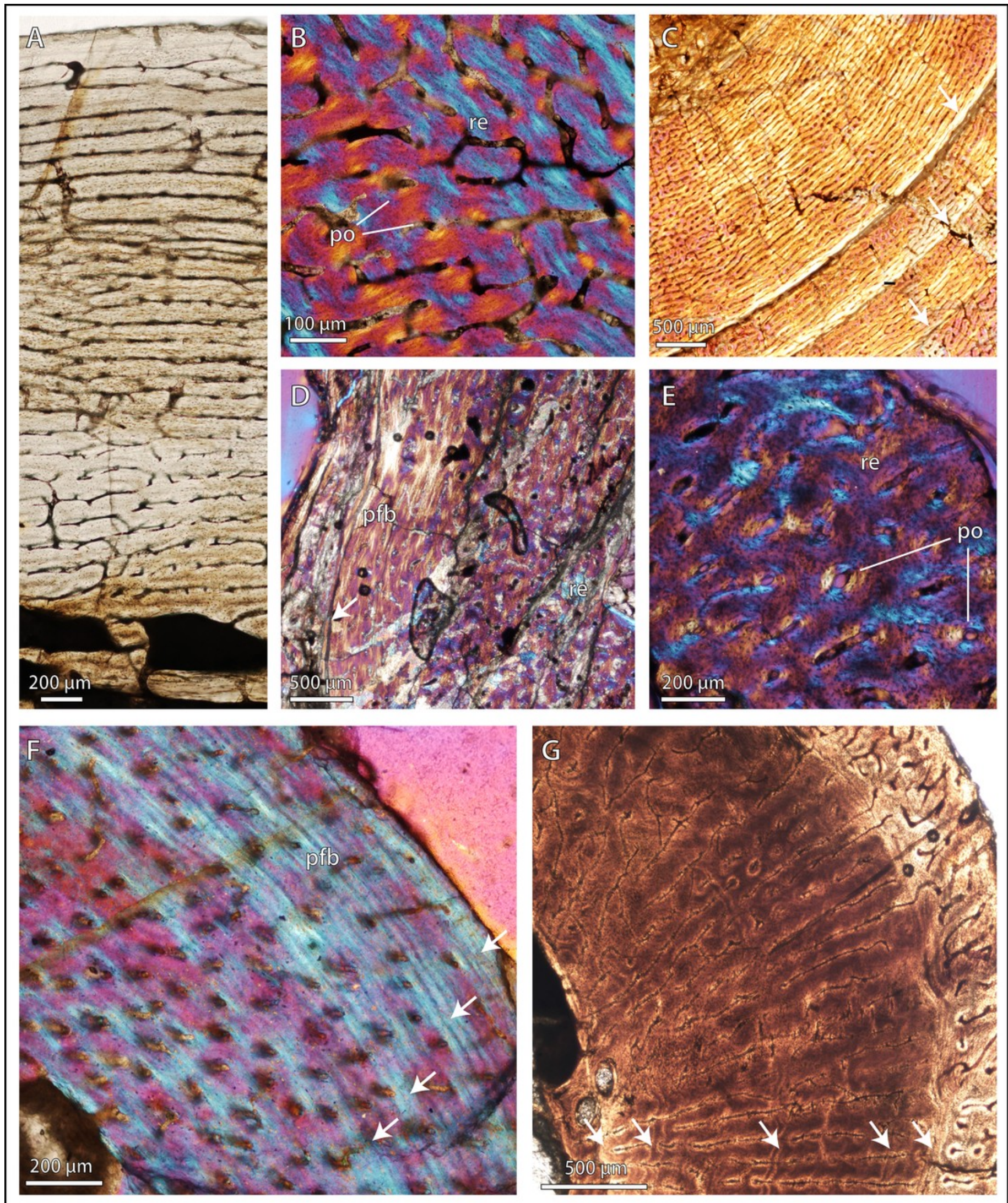


\section{Figure 3}

Bone microstructure in selected Permo-Triassic baurioid eutherocephalians.

A, Late Permian Ictidosuchoides subadult (SAM-PK-8659), radius midshaft, cortex and inner cancellous bony scaffold (crossed-nicols with wave plate). B, Ictidosuchoides adult (BP/1/4092), humerus midshaft, cortex with longitudinal and reticular primary osteons and growth marks (crossed-nicols with wave plate). C, Early Triassic Tetracynodon (NMQR 3745), humerus midshaft, cortex showing inner fibrolamellar bone and sparsely vascularized outer parallel-fibered bone (crossed-nicols with wave plate). D, Early Triassic Scaloposaurus (SAM-PK-K4638), humerus midshaft, cortex showing longitudinal and reticular fibrolamellar bone deposition followed by a thin collar of lamellar bone in the subperiosteal region (crossed-nicols with wave plate). E, Middle Triassic bauriid Microgomphodon (NMQR 3605), humerus midshaft, cortex showing reticular fibrolamellar bone with no growth marks (crossed-nicols with wave plate). F, Microgomphodon (NMQR 3605), femur midshaft, cortex showing reticular fibrolamellar bone (crossed-nicols with wave plate). Arrows denote growth marks. Detailed descriptions and photomicrographs are provided in the Supporting Data file. Abbreviations: pfb, parallel-fibered bone; re, reticular fibrolamellar bone. 

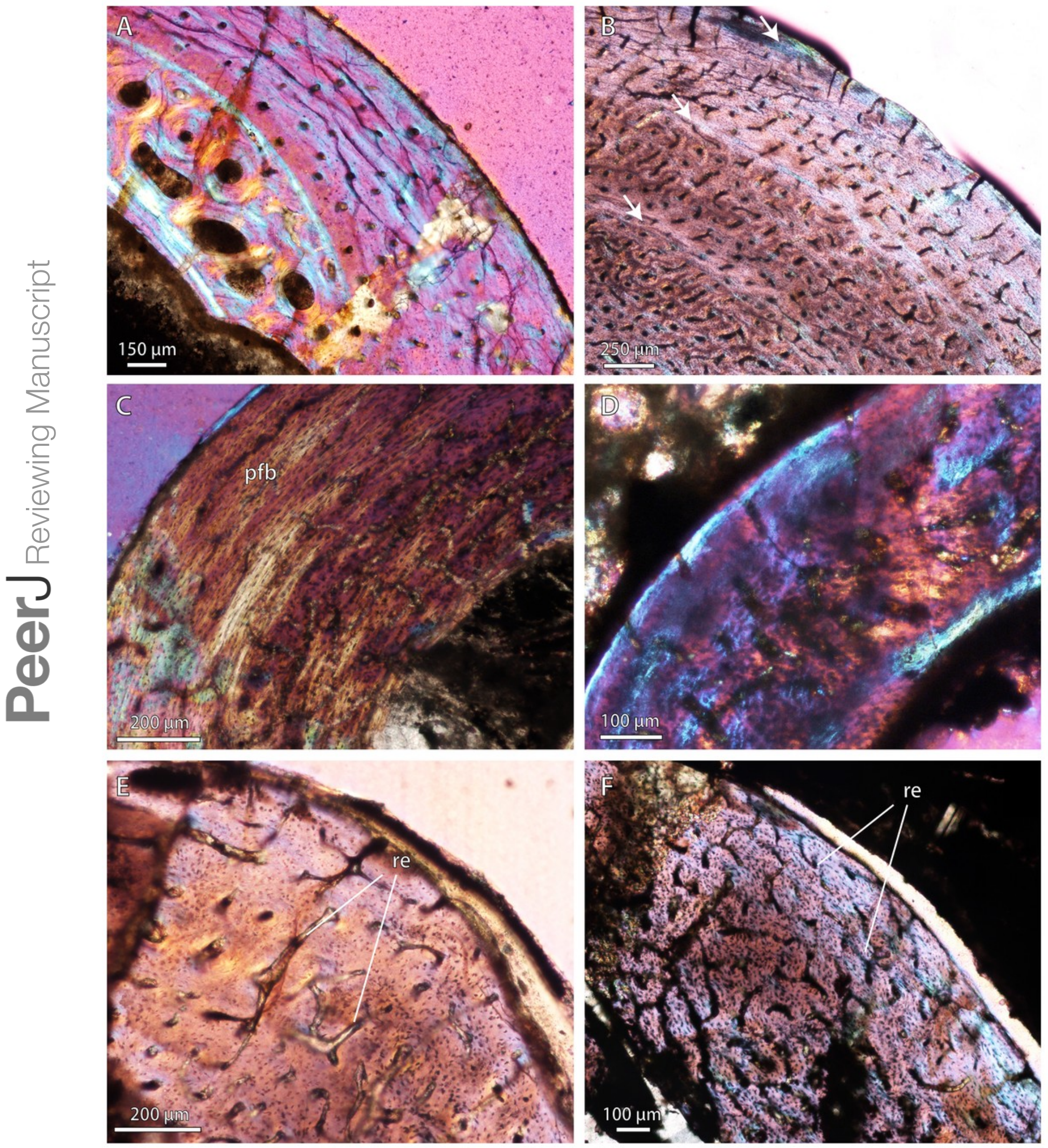


\section{Figure 4}

Linear regression of vascular growth proxies against size (midshaft cross-sectional area) from limb bone elements.

A, Mean cortical vascularity (\%CV) against midshaft cross-sectional area. B, Mean primary osteon diameter $(P O D)$ against midshaft cross-sectional area. $\mathbf{C}$, mean $\% \mathrm{CV}$ against mean $P O D$. All correlations between vascular growth proxies and size are strongly positively correlated for both propodials (solid regression line) and epipodials (dashed regression line) (see statistical results in Table 2). Blue circles $=$ propodials. Red circles = epipodials. 

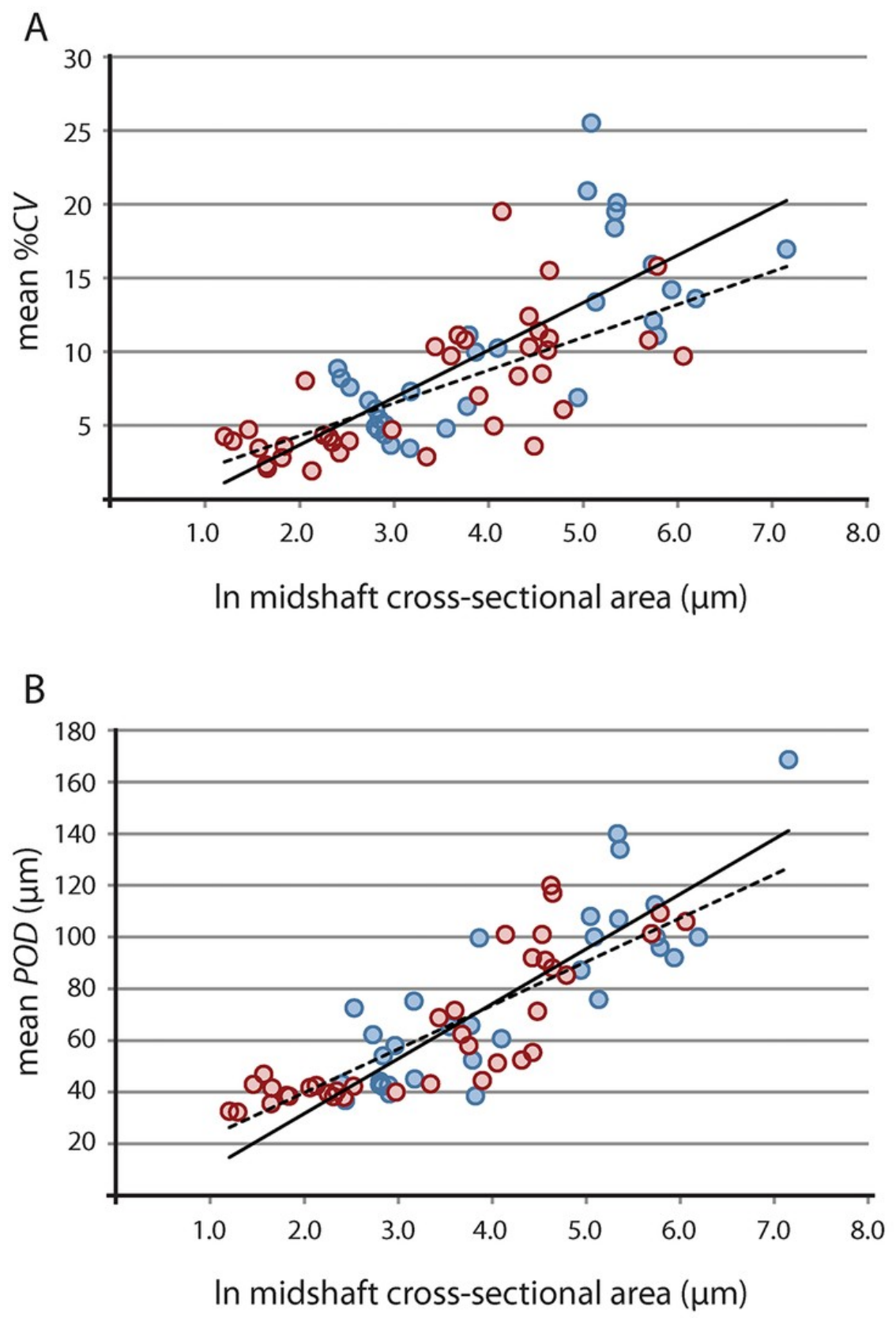

C

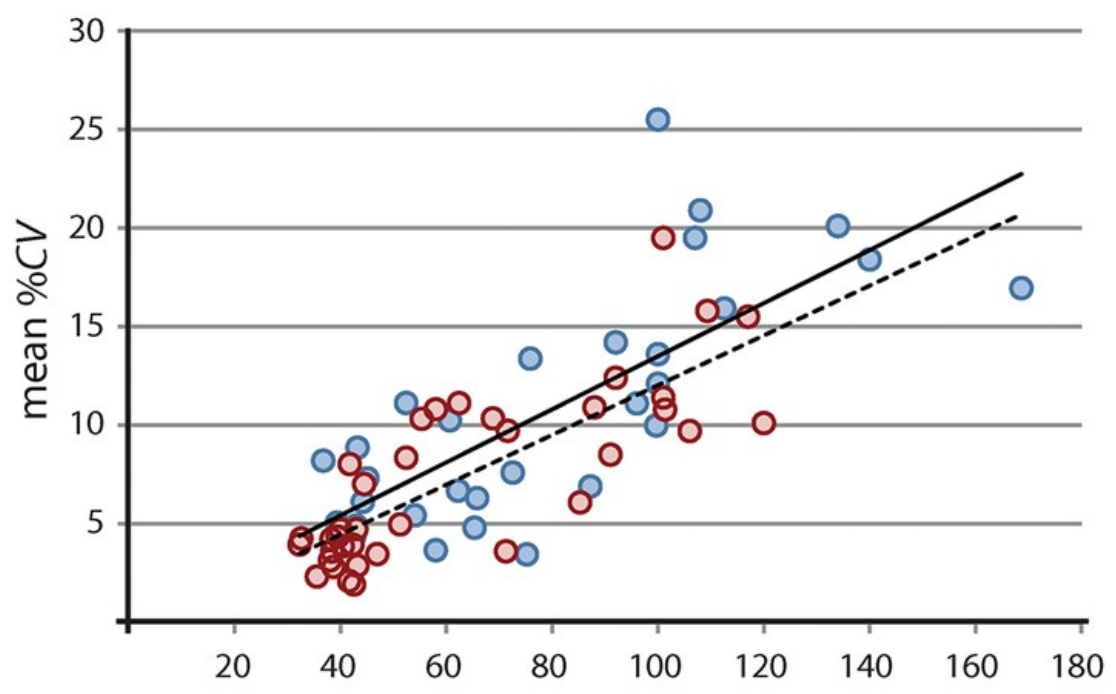

PeerJ reviewing PDF | (v2013:11: 1021 !:2:1:REW(um) Mar 2014) 


\section{Figure 5}

Comparison of bone histology and microvasculature in Permian Theriognathus and Moschorhinus.

A, Theriognathus (NMQR 3375) femur midshaft cortex (non-polarized light). B, Moschorhinus (NMQR 3939) humerus midshaft cortex (non-polarized light). Note the greater overall degree of vascularity in 'B.'
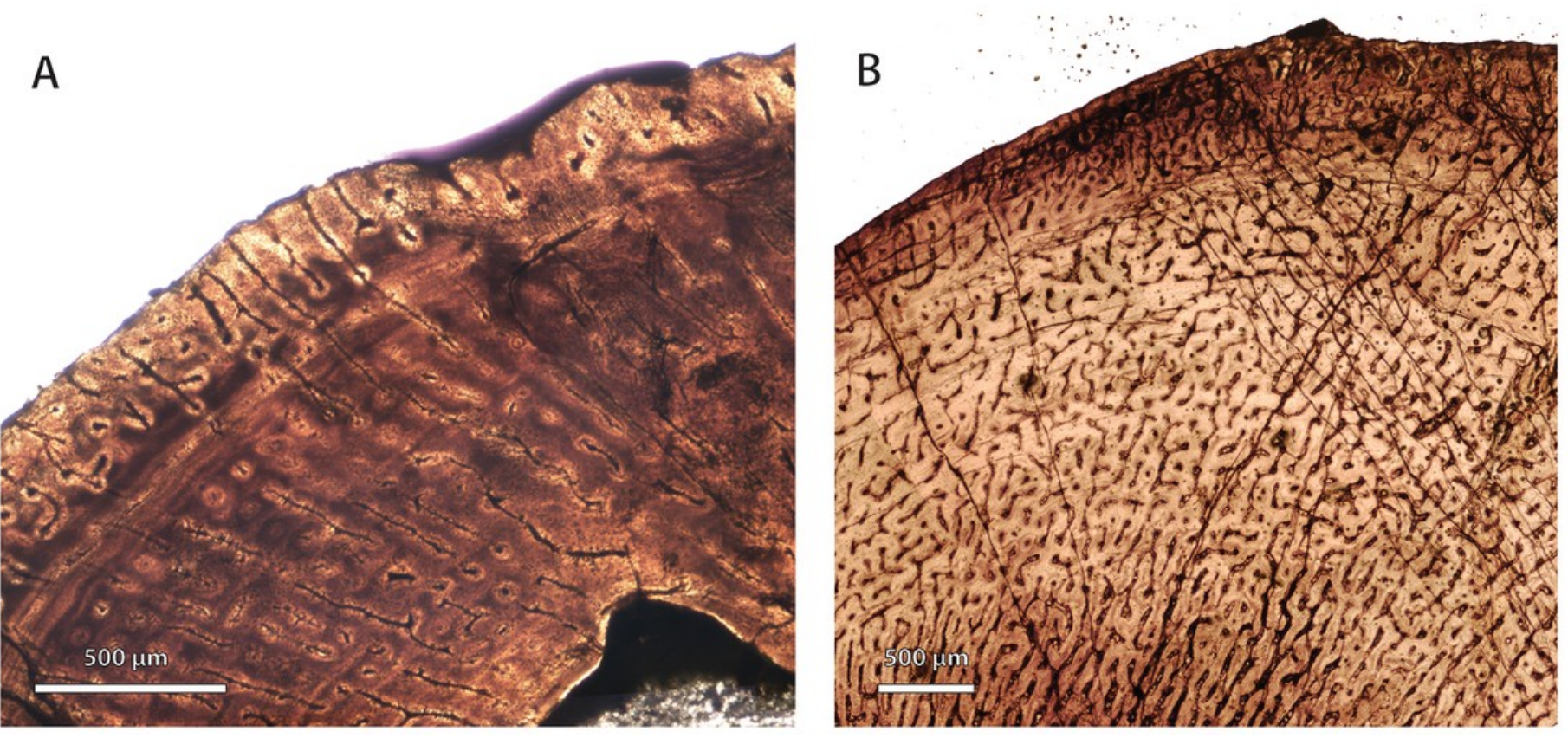


\section{Figure 6}

Mirror phylogenies of Permo-Triassic therocephalians sampled for bone histology (scaled to geologic time).

Phylogenetic character mapping of histological traits estimated from propodials (left) and epidpodials (right) reveals comparable ancestor-descendant changes for each pool of skeletal elements. A, average cortical vascularity (\%CV). B, average primary osteon diameter $(P O D)$. $\mathbf{C}$, relative bone wall thickness $(R B T)$. Ancestral states were reconstructed using squared-change parsimony in Mesquite version 2.0 (Maddison and Maddison, 2007). 
A

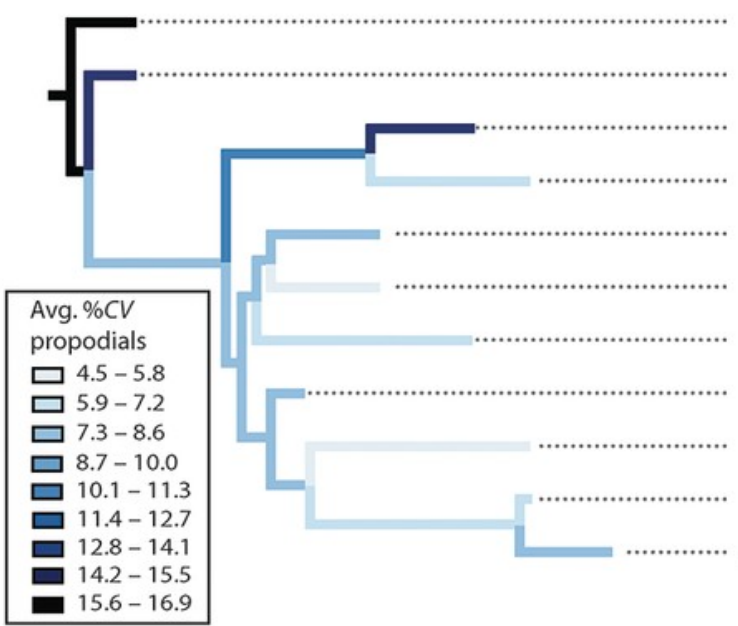

B

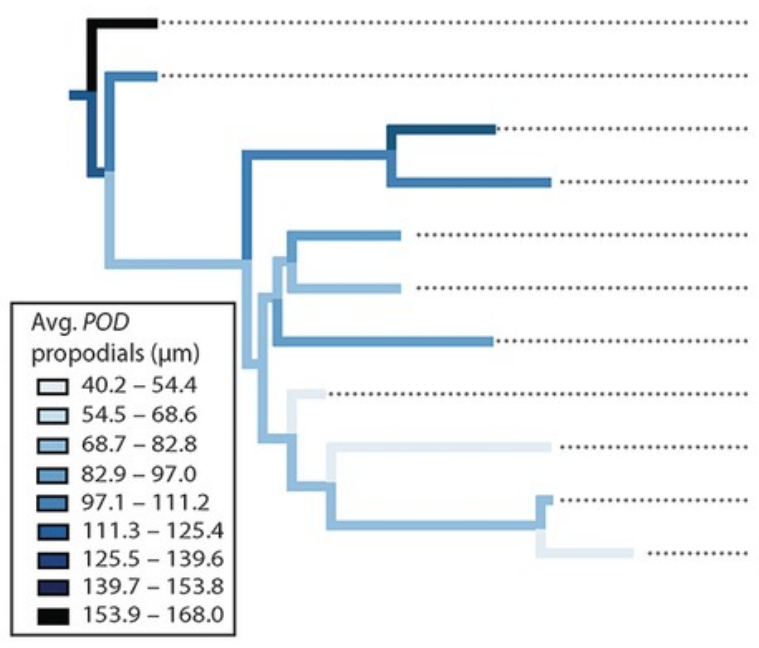

C

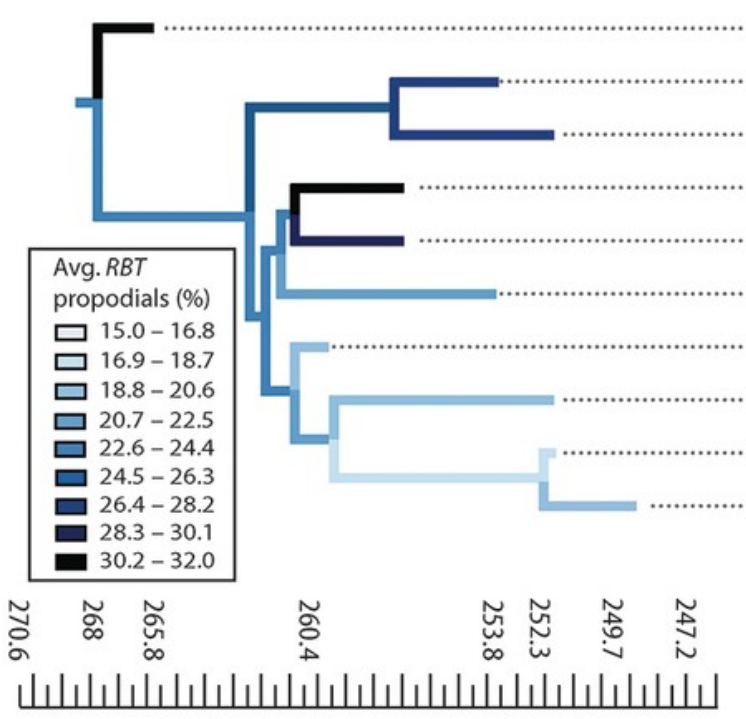

Estimated divergence time (Ma)
Lycosuchus

Scylacosauridae

Moschorhinus

Olivierosuchus

Hofmeyria

Mirotenthes

Theriognathus

Ictidosuchoides

Tetracynodon

Scaloposaurus

Microgomphodon

\section{Lycosuchus}

Scylacosauridae

Moschorhinus

Olivierosuchus

Hofmeyria

Mirotenthes

Theriognathus

Ictidosuchoides

Tetracynodon

Scaloposaurus

Microgomphodon

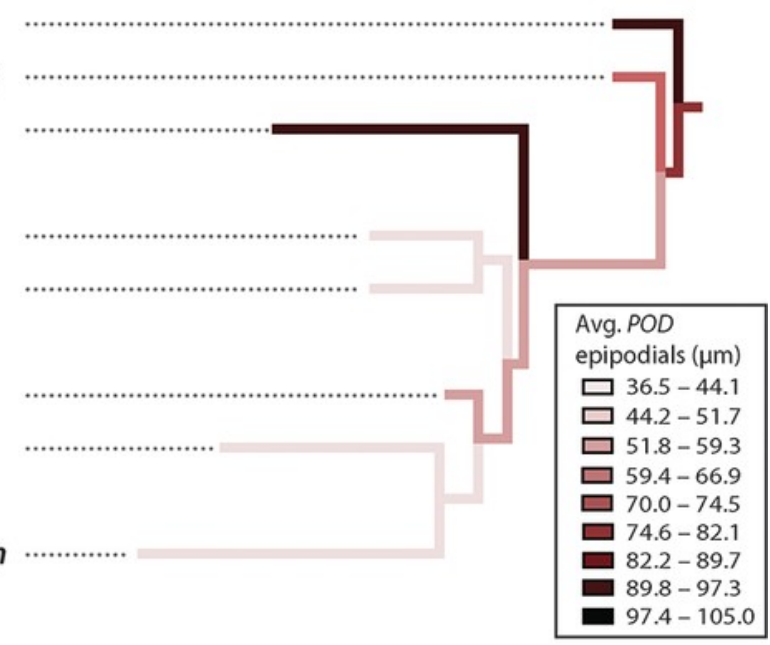

Lycosuchus

Scylacosauridae

Moschorhinus

Olivierosuchus

Hofmeyria

Mirotenthes

Theriognathus

Ictidosuchoides

Tetracynodon

Scaloposaurus

Microgomphodon

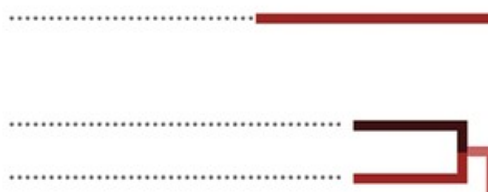

Avg. RBT

epipodials (\%)

$\square$ 20.5-22.4

$\square 22.5-24.4$

$\square 24.5-26.4$

$\square 26.5-28.3$

$\square 28.4-30.3$

- $30.4-32.3$

$32.4-34.2$

- $34.3-36.2$

- $36.3-38.2$ 


\section{Figure 7}

Summary of evolution of size and bone microstructural traits.

Black bars represent stratigraphic ranges of taxa that were sampled histologically. Numbers in parentheses to right of black bars denote maximum size of taxon in interval of first appearance. Tree topology and ranges from Huttenlocker, 2013 and 2014. In graph at top of figure, circles represent average \%CV and squares average POD of propodials (blue) and epipodials (red). Abbreviations: Chx, Changxingian; Cisteceph AZ, Cistecephalus Assemblage Zone; Cyn sub A, Cynognathus subzone A; Eodicyno AZ, Eodicynodon Assemblage Zone; Ind, Induan; Olen, Olenekian; Pristerog AZ, Pristerognathus Assemblage Zone; Roa, Roadian; Tapinoceph AZ, Tapinocephalus Assemblage Zone; Tropido AZ, Tropidostoma Assemblage Zone; Wor, Wordian. 

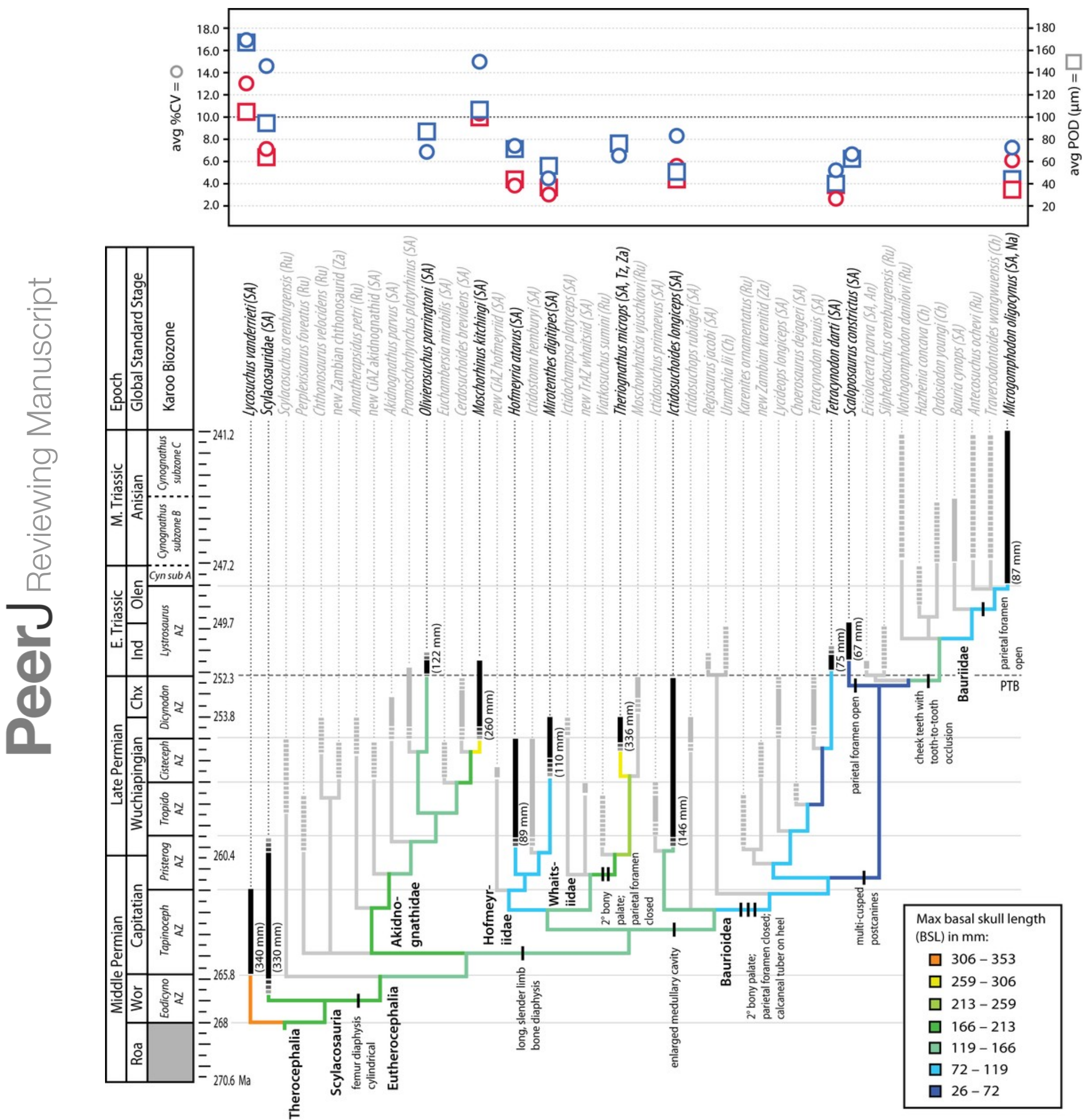